\title{
Competition between calcifying and noncalcifying temperate marine macroalgae under elevated $\mathrm{CO}_{2}$ levels
}

\author{
Laurie C. Hofmann*, Sandra Straub, Kai Bischof \\ Marine Botany, Bremen Marine Ecology Center for Research and Education, University of Bremen, Leobener Straße NW2, \\ 28359 Bremen, Germany
}

\begin{abstract}
Since pre-industrial times, uptake of anthropogenic $\mathrm{CO}_{2}$ by surface ocean waters has caused a documented change of $0.1 \mathrm{pH}$ units. Calcifying organisms are sensitive to elevated $\mathrm{CO}_{2}$ concentrations due to their calcium carbonate skeletons. In temperate rocky intertidal environments, calcifying and noncalcifying macroalgae make up diverse benthic photoautotrophic communities. These communities may change as calcifiers and noncalcifiers respond differently to rising $\mathrm{CO}_{2}$ concentrations. In order to test this hypothesis, we conducted an $86 \mathrm{~d}$ mesocosm experiment to investigate the physiological and competitive responses of calcifying and noncalcifying temperate marine macroalgae to 385, 665, and $1486 \mu$ atm $\mathrm{CO}_{2}$. We focused on comparing 2 abundant red algae in the Northeast Atlantic: Corallina officinalis (calcifying) and Chondrus crispus (noncalcifying). We found an interactive effect of $\mathrm{CO}_{2}$ concentration and exposure time on growth rates of $C$. officinalis, and total protein and carbohydrate concentrations in both species. Photosynthetic rates did not show a strong response. Calcification in C. officinalis showed a parabolic response, while skeletal inorganic carbon decreased with increasing $\mathrm{CO}_{2}$. Community structure changed, as Chondrus crispus cover increased in all treatments, while C. officinalis cover decreased in both elevated- $\mathrm{CO}_{2}$ treatments. Photochemical parameters of other species are also presented. Our results suggest that $\mathrm{CO}_{2}$ will alter the competitive strengths of calcifying and noncalcifying temperate benthic macroalgae, resulting in different community structures, unless these species are able to adapt at a rate similar to or faster than the current rate of increasing seasurface $\mathrm{CO}_{2}$ concentrations.
\end{abstract}

KEY WORDS: Competition · Corallina officinalis · Chondrus crispus · Calcification · Ocean acidification $\cdot$ Mesocosm

\section{INTRODUCTION}

Anthropogenic $\mathrm{CO}_{2}$ production is changing the chemistry of surface ocean waters, and since preindustrial times, uptake of $\mathrm{CO}_{2}$ by surface waters has caused a documented change of $0.1 \mathrm{pH}$ units (Caldeira \& Wickett 2003). The atmospheric $\mathrm{CO}_{2}$ concentration is expected to climb to $800-1000$ ppm by the year 2100 (Bindoff et al. 2007), and model simulations indicate they could even reach 1900 ppm by 2300 (Caldeira \& Wickett 2003, Orr et al. 2005). The atmospheric $\mathrm{CO}_{2}$ levels expected in 2100 would result in a decrease of surface seawater $\mathrm{pH}$ of 0.3 to 0.5 units (Caldeira \& Wickett 2005, Orr et al. 2005). Recent research on the consequences of these changes on marine organisms has shown varied responses across multiple taxonomic levels (Fabry 2008, Ries 2009, Kroeker et al. 2010, Fabricius et al. 2011, Rodolfo-Metalpa et al. 2011). In general, calcifying organisms seem to be the most sensitive (Kroeker et al. 2010), but even among calcifiers, the response to elevated $\mathrm{CO}_{2}$ is not consistent (Fabry 2008, Ries 2009, Fabricius et al. 2011). 
Calcifying benthic photoautotrophs may be particularly susceptible to the elevated surface-seawater $\mathrm{CO}_{2}$ concentrations as they are sessile (as adults) and rely on $\mathrm{CO}_{2}$ as the substrate for photosynthesis. Benthic marine macroalgae are ecologically important as they provide food, refugia, and substrata for diverse marine communities (Paine \& Vadas 1969, Lubchenco 1978, Littler \& Littler 1984, Gibbons \& Griffiths 1986, Eriksson et al. 2006). Therefore, they are essential organisms to study within the context of future climate change. Several authors have investigated the responses of noncalcifying macroalgae to elevated $\mathrm{CO}_{2}$ concentrations (e.g. Gao et al. 1991, 1993, Mercado et al. 1999, Gordillo et al. 2001, Zou 2005, Cornwall et al. 2012), and have found varied responses. However, calcifying macroalgae, particularly high-magnesium calcite-depositing coralline algae, show pronounced sensitivity to elevated $\mathrm{CO}_{2}$ concentrations with respect to calcification rates, necrosis, mortality, and recruitment (Jokiel et al. 2008, Kuffner et al. 2008, Martin et al. 2008, Büdenbender et al. 2011, Hofmann et al. 2012, Porzio et al. 2011). Due to the variable reactions of noncalcifying and calcifying macroalgae to elevated $\mathrm{CO}_{2}$, it is likely that macroalgal communities will show considerable changes in structure and diversity in future oceans. Indeed, tropical community studies have shown that crustose calcifying algae decrease growth rate, cover, and recruitment, while noncalcifying algae show a subsequent increase in cover under elevated $\mathrm{CO}_{2}$ conditions (Jokiel et al. 2008, Kuffner et al. 2008). Furthermore, Porzio et al. (2011) recently reported that macroalgal species diversity, abundance, and reproduction changes along a natural $\mathrm{CO}_{2}$ gradient in the Mediterranean. They found that calcitic algae decreased in cover and species richness with decreasing $\mathrm{pH}$. Such a change in macroalgal community structure could have profound effects on the marine fauna, to which coralline algae provide structural support, substrata, and refugia (Bak 1976, Stewart 1982, Coull \& Wells 1983, Akioka et al. 1999).

Several studies have shown significant effects of $\mathrm{CO}_{2}$ on warm-water communities (Jokiel et al. 2008, Kuffner et al. 2008, Porzio et al. 2011). However, little attention has been given to temperate macroalgal communities outside of the Mediterranean, despite the fact that both crustose and articulated coralline algae co-exist with noncalcifying species in diverse macroalgal communities (Hall-Spencer et al. 2008, Martin et al. 2008, Hepburn et al. 2011, Porzio et al. 2011, Russell et al. 2011). Therefore, diverse macroalgal communities provide an ideal platform for investigating the physiological ecology of macroalgal responses to elevated $\mathrm{CO}_{2}$ concentrations, particularly with respect to their competitive interactions. Demonstrating changes in community structure in response to an external stress is often the main goal of large-scale mesocosm and field-manipulation experiments. However, it is also important to understand the physiology behind the species-specific responses of co-existing organisms to external stress, and how those responses affect competitive interactions that are reflected in community structure and function. To date, no studies have directly linked elevated $\mathrm{CO}_{2}$-related physiological responses of temperate macroalgal communities to competition between calcifiers and noncalcifiers and the ecological consequences of such competition. Therefore, we conducted a mesocosm experiment over $87 \mathrm{~d}$ to determine how the physiology of calcifying and noncalcifying benthic temperate macroalgae is affected by elevated $\mathrm{CO}_{2}$ levels, how these physiological responses affect their competition, and finally, if changes in competition strengths are reflected at the community level.

\section{MATERIALS AND METHODS}

\section{Experimental design and seawater chemistry}

On 16 March 2011, macroalgal communities were collected from the coast of Helgoland, Germany where they grow attached to red sandstone rocks in the intertidal zone. We chipped away the rocks using hammers and chisels. As a result, the experimental communities remained intact and attached to their natural substratum. All communities contained the calcifier Corallina officinalis and its associated counterparts, which at the time consisted of mostly the noncalcifying red algae Chondrus crispus, Dumontia incrassata, Polysiphonia fucoides, and red calcifying crustose algae. The communities were kept in running seawater overnight, and transported to the Wadden Sea Station of the Alfred Wegener Institute on the North Sea island of Sylt, where the experiment was conducted.

The algae were acclimated to the ambient Wadden Sea seawater in a large outdoor tank with filtered running seawater for 1 wk before initial measurements were taken. The seawater was double-filtered, first with a protein skimmer (Model III P with 20001 $\mathrm{h}^{-1}$ flow rate, Sander Elektroapparatebau) and then with a UV filter (Model 4000/75 Watt, Wiegandt). During the acclimation week, the mesocosms were prepared and the seawater chemistry was monitored. 
The mesocosms were cylindrical plexiglass tanks $60 \mathrm{~cm}$ tall and $40 \mathrm{~cm}$ in diameter. They were surrounded by $2000 \mathrm{l}$ of continuously running seawater for temperature control. The mesocosms also received continuously running seawater and were rigorously bubbled with 1 of $3 \mathrm{CO}_{2}$ concentrations: $385 \mu \mathrm{atm}$ (ambient), $665 \mu \mathrm{atm}$, and $1486 \mu \mathrm{atm} \mathrm{CO}_{2}$. The $\mathrm{CO}_{2}$ concentrations were achieved using an HTK 5-channel gas mixing system. Each $\mathrm{CO}_{2}$ treatment contained 4 tanks $(n=4)$ and 1 control tank (not furnished with algae).

Once the water chemistry was stable and the algae were acclimated to ambient light and seawater conditions, initial photochemical and photosynthesis measurements were taken, tissue samples were frozen in liquid nitrogen and stored at $-80^{\circ} \mathrm{C}$ for later analysis, and photographs of each community were taken before the communities were sorted randomly into the 12 treatment tanks. Each tank contained 1 rock with exclusively Corallina officinalis for growth measurements, 1 rock with only $C$. officinalis and Chondrus crispus, and 1 rock containing C. officinalis in a more diverse community ( $>3$ species).

The $\mathrm{pH}$, temperature, and salinity in each tank were monitored twice daily. Water samples for total alkalinity and nutrient analysis were taken weekly. Total alkalinity was measured using a TitroLine alpha 05 plus titrator with an automated sample changer and IoLine IL-Micro pH electrode (SI Analytics). Salinity and temperature were measured using a Portamess 910 Cond conductivity meter, and $\mathrm{pH}$ was measured using a WTW SenTix $41 \mathrm{pH}$ electrode connected to a WTW pH 3310 portable $\mathrm{pH}$ meter. The physiological response variables and analysis of community structure were measured monthly. The experiment lasted for $86 \mathrm{~d}$, from March 28 to June 24, 2011.

\section{Growth and calcification of calcifying rhodophyte Corallina officinalis}

Growth of Corallina officinalis was measured by staining the algae thalli. Each treatment tank contained a rock on which only $C$. officinalis was growing. The algae growing on these rocks were stained for 12 to $24 \mathrm{~h}$ in alizarin red stain (Rivera et al. 2004) for growth measurements based on length increase. Multiple tips of multiple thalli were measured and averaged for each tank, and this value was counted as 1 replicate.

Calcification rates were determined by measuring the total alkalinity $\left(A_{\mathrm{T}}\right)$ of seawater before and after
$2 \mathrm{~h}$ incubations in small incubation chambers $(10 \mathrm{~cm}$ diameter $\times 30 \mathrm{~cm}$ height). One rock carrying only Corallina officinalis was placed into each chamber during the incubations, which were continuously bubbled with the respective premixed $\mathrm{CO}_{2}$ treatment levels. Net calcification rates were calculated according to the equation:

$$
G_{\text {net }}=-0.5 \rho_{\mathrm{w}}(V / S) \times\left(\Delta A_{\mathrm{T}} / \Delta t\right)
$$

where $G_{\text {net }}$ is net calcification rate $\left(\mu \mathrm{mol} \mathrm{CaCO}_{3} \mathrm{~m}^{-2}\right.$ $\left.\mathrm{h}^{-1}\right), \rho_{\mathrm{w}}$ is seawater density $\left(\mathrm{kg} \mathrm{l}^{-1}\right), V$ is seawater volume (l), $S$ is surface area of the algal assemblage $\left(\mathrm{m}^{2}\right), \Delta A_{\mathrm{T}}$ is change in alkalinity during the incubation, and $\Delta t$ is incubation period (h). The percentage of the dry weight (DW) of $C$. officinalis thalli consisting of inorganic carbon was measured by determining the ash-free dry weight (AFDW) of the tissue. Thalli fragments were dried for $48 \mathrm{~h}$ at $50^{\circ} \mathrm{C}$, weighed, placed into pre-burned and pre-weighed crucibles, and incinerated at $400^{\circ} \mathrm{C}$ for $24 \mathrm{~h}$. The relative percentage of the DW consisting of inorganic carbon was calculated as (AFDW/DW) $\times 100 \%$.

\section{Physiological responses of Corallina officinalis vs. Chondrus crispus}

\section{Photosynthesis}

Respiration and oxygen production in Corallina officinalis and Chondrus crispus were measured as outlined in Hofmann et al. (2012), with the modification of 3 min light intervals during photosynthesisirradiance $(P-E)$ curve measurements. Respiration was measured in the dark for 15 min prior to the light steps, which consisted of light intensities ranging from 0 to $1000 \mu \mathrm{mol}$ photons $\mathrm{m}^{-2} \mathrm{~s}^{-1}$. Oxygen consumption/production was measured using a Hansatech Chlorolab 3 System (Hansatech Instruments). Maximum photosynthesis rate $\left(P_{\max }\right)$, photosynthetic efficiency $(\alpha)$, and light saturation point $\left(E_{\mathrm{k}}\right)$ were calculated from nonlinear regression analyses based on the model from Eilers \& Peeters (1988).

\section{Concentration of phycobilins, soluble proteins, and carbohydrates}

The method for measuring phycobilin, protein, and carbohydrate concentrations in a single algal extract was done according to Andria et al. (1999). Algal thalli (100 to $200 \mathrm{mg}$ ) previously frozen in liquid 
nitrogen and stored at $-80^{\circ} \mathrm{C}$ were ground to a fine powder in pre-chilled shaking flasks using a MikroDismembrator (B. Braun Biotech International). The algal powder was suspended in 5 to $10 \mathrm{ml}$ of cold $0.1 \mathrm{M}$ phosphate buffer ( $\mathrm{pH}$ 6.8) and kept in the dark at $4{ }^{\circ} \mathrm{C}$ overnight. The resulting algal extract was split into 3 supernatant fractions that were used for subsequent pigment, protein, and carbohydrate analysis. The pellet was used to determine insoluble carbohydrate content. Methods for measuring phycoerythrin and phycocyanin were taken from Beer \& Eshel (1985), protein precipitation was conducted according to Barbarino \& Lourenço (2005), and protein concentration was determined by the Bradford method (Bradford 1976). The phenol sulfuric acid method was used to determine soluble and insoluble carbohydrate concentrations (Kochert 1978).

\section{Community analysis}

Photochemistry of macroalgal communities

Photochemical parameters of the entire macroalgal communities were measured using a Maxi-ImagingPAM (pulse amplitude modulated) chlorophyll fluorometer (Walz) equipped with a blue LED-Array illumination unit and a CCD Camera with $1392 \times 1040$ pixels (Pike, Allied Vision Technologies). The chlorophyll fluorescence measured by the PAM was digitized by the camera and transferred to a $\mathrm{PC}$, which allows the user to obtain an image of the chlorophyll fluorescence for a large area, including mixed communities. The communities were immersed in a beaker containing their treatment water and darkadapted for 5 min prior to photochemical analysis. Following dark adaptation, the chlorophyll fluorometer measured the dark fluorescence yield $\left(F_{0}\right)$ and maximum fluorescence $\left(F_{\mathrm{m}}\right)$ for the entire community. From these parameters, the maximal photosystem II (PS II) quantum yield $F_{\mathrm{v}} / F_{\mathrm{m}}$ was calculated according to the equation:

$$
F_{\mathrm{v}} / F_{\mathrm{m}}=\left(F_{\mathrm{m}}-F_{\mathrm{o}}\right) / F_{\mathrm{m}}
$$

where $F_{\mathrm{v}}$ is variable fluorescence, or the difference between $F_{\mathrm{m}}$ and $F_{\mathrm{o}}$. Then the communities were exposed to a series of pre-defined increasing photosynthesis-saturating light pulses at $20 \mathrm{~s}$ intervals, and the effective PS II quantum yield $(Y)$ was measured after each pulse. The relative electron transport rates $(r$ ETR) were then calculated using the equation:

$$
r \mathrm{ETR}=0.5 \times Y \times \mathrm{PAR}
$$

where PAR is light intensity of each saturation pulse ( $\mu \mathrm{mol}$ photons $\mathrm{m}^{-2} \mathrm{~s}^{-1}$ ). The factor 0.5 accounted for the 2 quanta that must be absorbed for every electron transported due to the presence of 2 photosystems. The resulting values were used to produce $r$ ETR versus irradiance curves, from which we calculated the maximum $r$ ETR $\left(r \mathrm{ETR}_{\max }\right), E_{\mathrm{k}}$, and the electron transport rate efficiency $(\alpha)$ using the nonlinear model from Eilers \& Peeters (1988).

Percent cover, diversity, and dominance

Digital photographs of each macroalgal community were taken monthly and analyzed for percent cover of individual species and community diversity and dominance indexes using the Coral Point Count with Excel extensions (CPCe) software (Kohler \& Gill 2006). A $10 \times 10$ point grid was overlaid on each photograph, and the species that occurred at each point in the community was recorded for the analysis. The percent change in cover was calculated by relating the percent cover of each species over time to the initial percent cover of that species according to the equation $\left[\left(\%\right.\right.$ cover $\left.\left._{t}-\% \operatorname{cover}_{i}\right) / \% \operatorname{cover}_{i}\right] \times 100$, where $\mathrm{t}$ is Day 36 or 86, and i is initial.

\section{Statistical analysis}

Statistical analyses were applied to test for significance at the $95 \%(\mathrm{p}<0.05)$ confidence level. When a single response variable for one species was analyzed, a 1-way ANOVA was conducted followed by pairwise comparisons using a Tukey HSD test. When a single response variable was measured over time, a repeated-measures ANOVA was conducted using time as a within-subject factor and $\mathrm{CO}_{2}$ as the between-subject factor. For analysis of multiple response variables from multiple species over time, a mixed factorial multivariate analysis of variance (MANOVA) was conducted including time as a within-subject factor and $\mathrm{CO}_{2}$ and species as between-subject factors. A Tukey HSD test was used for pairwise comparisons. For the analysis of proteins, carbohydrates, and phycobiliproteins, the MANOVA was followed by a discriminant analysis. If the data were not normally distributed, they were transformed to fit the assumptions of an ANOVA. When the data did not meet Mauchly's test of sphericity, the degrees of freedom were corrected using Greenhouse-Geisser estimates of sphericity. Separate MANOVAs were conducted for P-E curve 
parameters, chlorophyll a fluorescence parameters, and tissue content, because the sampling technique and time of these analyses were slightly different. Correlation analysis was conducted by calculating Pearson's correlation coefficient (Pearson's r) of 2 variables using a 1-tailed test for significance.

\section{RESULTS}

\section{Seawater chemistry}

Seawater chemistry parameters are outlined in Table 1. The mean $\mathrm{CO}_{2}$ concentrations in the tanks containing algal communities were slightly lower than the means measured in control tanks, indicating that the algal communities took up $\sim 1 \%$ of the dissolved $\mathrm{CO}_{2}$. The seawater in the highest- $\mathrm{CO}_{2}$ treatment tanks was saturated with calcite $\left(\Omega_{\text {calcite }}>1\right)$, and undersaturated with aragonite $\left(\Omega_{\text {aragonite }}<1\right)$. Weekly measurements of inorganic nitrogen and phosphorus concentrations (nitrate and phosphate) showed seasonal fluctuations. Nitrate concentrations ranged from 7 to $40 \mu \mathrm{M}$, and were highest at the beginning of the experiment and lowest after $40 \mathrm{~d}$. Phosphate concentrations started at $0.19 \mu \mathrm{M}$ and steadily increased during the experiment, with a maximum concentration of $0.94 \mu \mathrm{M}$. The increase in phosphate concentration over time was most likely due to the decomposition of spring phytoplankton blooms.

\section{Growth and calcification of Corallina officinalis}

The growth rate of Corallina officinalis after $74 \mathrm{~d}$ was influenced by a main effect of $\mathrm{CO}_{2}$ concentration (1-way ANOVA: $\mathrm{df}=2, F=9.439, \mathrm{p}=0.008$ ). It was highest at $385 \mu \mathrm{atm} \mathrm{CO}_{2}$ and lowest at $1485 \mu \mathrm{atm} \mathrm{CO}_{2}$
(Fig. 1). Calcification rates showed a parabolic relationship to seawater aragonite saturation states $\left(\Omega_{\text {ara- }}\right.$ gonite), with the highest rate measured at $\Omega_{\text {aragonite }}=$ 1.65, which corresponded to the $665 \mu \mathrm{atm} \mathrm{CO}_{2}$ treatment (Fig. 2a). There was no significant difference between calcification rates at the highest and lowest $\mathrm{CO}_{2}$ level. However, after $30 \mathrm{~d}$, the skeletal inorganic carbon of C. officinalis was significantly positively correlated to aragonite saturation state (linear regression analysis: $r^{2}=0.535, p=0.007$ ), and this relationship remained consistent throughout the remainder of the experimental period (Fig. $2 b$; time series data not shown). Furthermore, there was an inverse relationship between calcification rate and skeletal inorganic carbon when inorganic carbon was above $77.1 \%$ of the dry weight; below that point, there was no clear relationship between skeletal inorganic carbon and

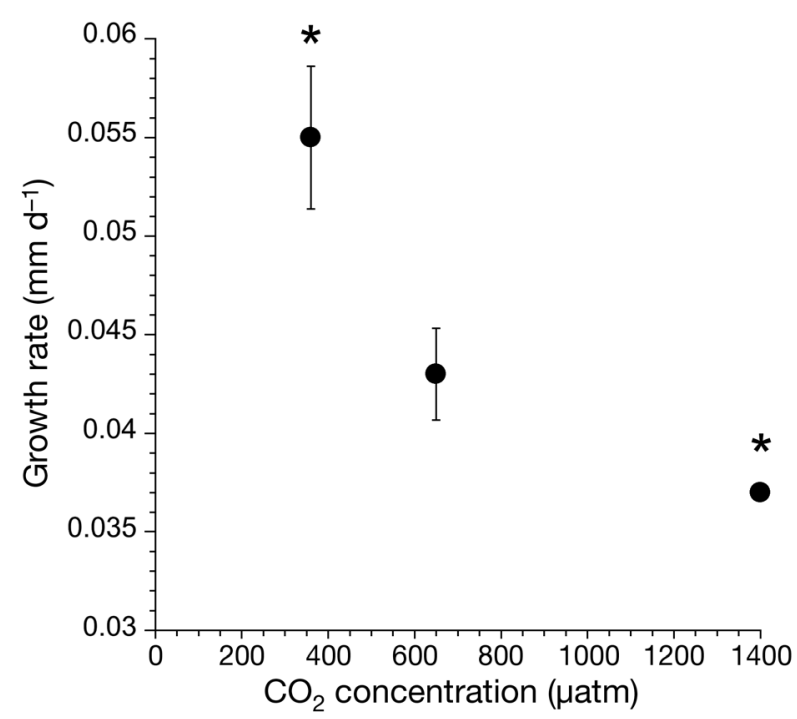

Fig. 1. Corallina officinalis. Growth rates (means $\pm \mathrm{SE}$ ) after $74 \mathrm{~d}$ exposure to $\mathrm{CO}_{2}$ treatments, based on length measurements of new material that appeared after staining with alizarin red. * Significant differences in growth rates between $\mathrm{CO}_{2}$ concentrations $(F=9.439, \mathrm{p}=0.008)$

Table 1. Seawater (SW) parameters for $\mathrm{CO}_{2}$-treated tanks without algae (regular font) and with algae (bold) calculated from daily measurements throughout the experiment. Algae in the tanks produced slightly lower $\mathrm{CO}_{2}$ concentrations compared to the tanks without algae due to metabolic uptake of dissolved $\mathrm{CO}_{2} . \Omega_{\text {calcite }}$ : calcite saturation state, $\Omega_{\text {aragonite }}$ : aragonite saturation state

\begin{tabular}{|c|c|c|c|c|c|c|c|}
\hline $\begin{array}{l}\mathrm{CO}_{2} \\
\text { treatment }\end{array}$ & $\begin{array}{l}\mathrm{pCO}_{2} \\
\text { ( } \mu \text { atm) }\end{array}$ & $\mathrm{pH}$ & $\begin{array}{c}{\left[\mathrm{CO}_{2}\right]} \\
\left(\mu \mathrm{mol} \mathrm{kg}{ }^{-1} \mathrm{SW}\right)\end{array}$ & $\begin{array}{c}{\left[\mathrm{HCO}_{3}^{-}\right]} \\
\left(\mu \mathrm{mol} \mathrm{kg}{ }^{-1} \mathrm{SW}\right)\end{array}$ & $\begin{array}{c}{\left[\mathrm{CO}_{3}{ }^{2-}\right]} \\
\left(\mu \mathrm{mol} \mathrm{kg}{ }^{-1} \mathrm{SW}\right)\end{array}$ & $\Omega_{\text {calcite }}$ & $\Omega_{\text {aragonite }}$ \\
\hline Ambient & $\begin{array}{l}385 \pm 20 \\
\mathbf{3 7 1} \pm \mathbf{1 1}\end{array}$ & $\begin{array}{l}8.22 \pm 0.02 \\
\mathbf{8 . 2 5} \pm \mathbf{0 . 0 1}\end{array}$ & $\begin{array}{l}16.1 \pm 0.94 \\
\mathbf{1 6 . 5} \pm \mathbf{0 . 5 8}\end{array}$ & $\begin{array}{l}1980 \pm 24 \\
2010 \pm 28\end{array}$ & $\begin{array}{l}150 \pm 8 \\
\mathbf{1 6 1} \pm \mathbf{4}\end{array}$ & $\begin{array}{l}3.71 \pm 0.2 \\
\mathbf{4 . 0 0} \pm \mathbf{0 . 1}\end{array}$ & $\begin{array}{l}2.33 \pm 0.1 \\
\mathbf{2 . 5 2} \pm \mathbf{0 . 1}\end{array}$ \\
\hline Medium & $\begin{array}{l}665 \pm 36 \\
\mathbf{6 0 2} \pm \mathbf{1 5}\end{array}$ & $\begin{array}{l}8.01 \pm 0.02 \\
\mathbf{8 . 0 5} \pm \mathbf{0 . 0 1}\end{array}$ & $\begin{array}{l}28.1 \pm 1.7 \\
\mathbf{2 5 . 4} \pm \mathbf{0 . 7 2}\end{array}$ & $\begin{array}{l}2103 \pm 19 \\
\mathbf{2 0 8 8} \pm \mathbf{1 0}\end{array}$ & $\begin{array}{r}98 \pm 6 \\
\mathbf{1 0 6} \pm \mathbf{3}\end{array}$ & $\begin{array}{l}2.44 \pm 0.2 \\
\mathbf{2 . 6 2} \pm \mathbf{0 . 1}\end{array}$ & $\begin{array}{l}1.53 \pm 0.1 \\
\mathbf{1 . 6 5} \pm \mathbf{0 . 1}\end{array}$ \\
\hline High & $\begin{array}{l}1486 \pm 73 \\
\mathbf{1 3 8 0} \pm \mathbf{4 3}\end{array}$ & $\begin{array}{l}7.69 \pm 0.02 \\
\mathbf{7 . 7 3} \pm \mathbf{0 . 0 1}\end{array}$ & $\begin{array}{l}62.4 \pm 3.4 \\
\mathbf{5 8 . 3} \pm \mathbf{2 . 1}\end{array}$ & $\begin{array}{l}2230 \pm 13 \\
\mathbf{2 2 4 2} \pm \mathbf{3 0}\end{array}$ & $\begin{array}{l}49 \pm 3 \\
\mathbf{5 5} \pm \mathbf{2}\end{array}$ & $\begin{array}{l}1.22 \pm 0.1 \\
\mathbf{1 . 3 6} \pm \mathbf{0 . 1}\end{array}$ & $\begin{array}{l}0.77 \pm 0.1 \\
\mathbf{0 . 8 5} \pm \mathbf{0 . 0 3}\end{array}$ \\
\hline
\end{tabular}



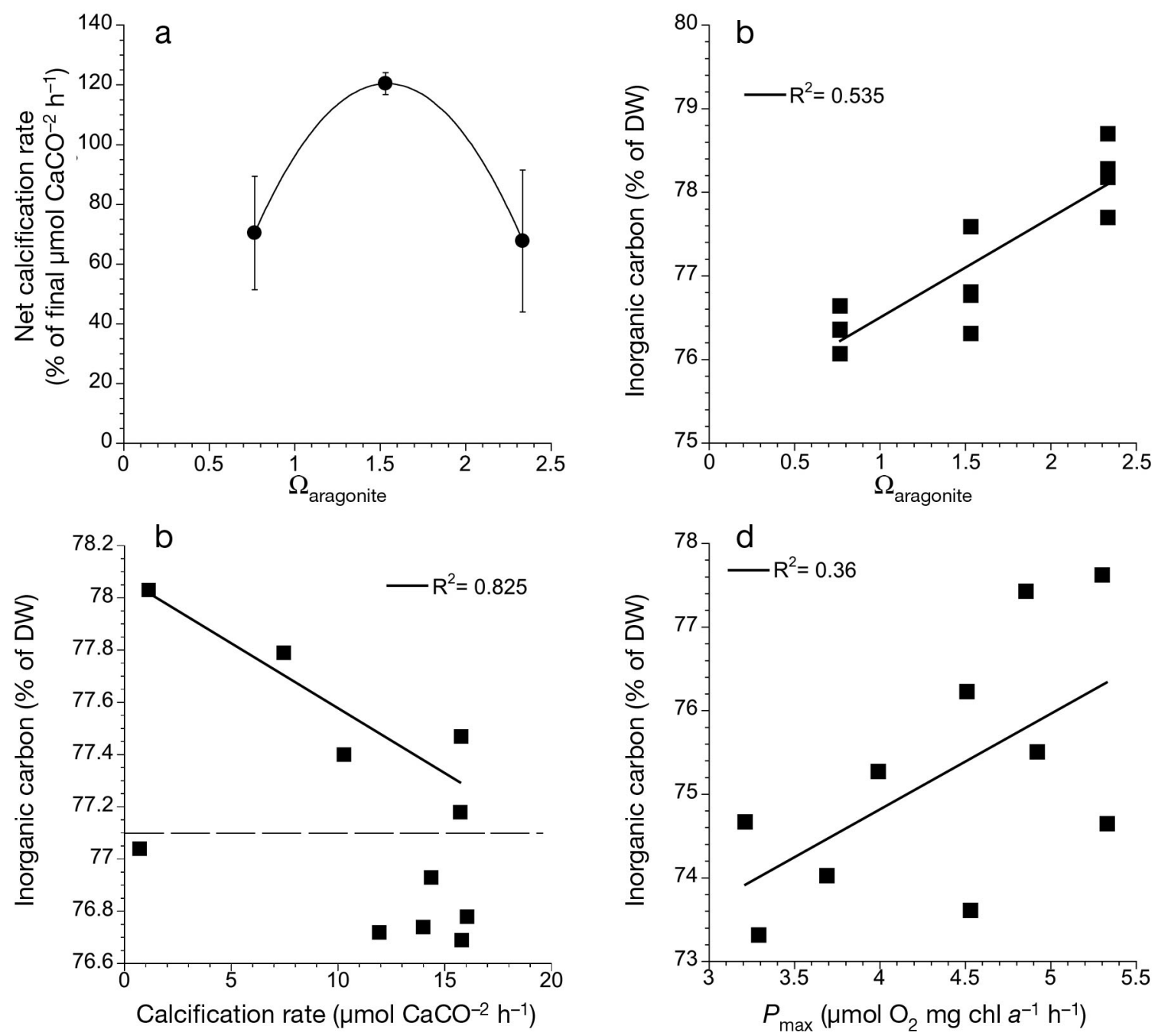

Fig. 2. Corallina officinalis. (a) Calcification rates after $38 \mathrm{~d}$ exposure to $\mathrm{CO}_{2}$ treatments as a function of aragonite saturation state $\left(\Omega_{\text {aragonite, }}\right.$ means \pm SE). (b) Percent inorganic carbon of thalli dry weight (DW) as a function of $\Omega_{\text {aragonite. (c) Relationship }}$ between inorganic carbon and calcification rate, showing a linear relationship above a cut-off point at $77.1 \%$. (d) Inorganic carbon versus maximum photosynthesis rate $\left(P_{\max }\right)$

calcification rate (Fig. 2c). In contrast, there was a positive correlation between inorganic carbon and maximum photosynthetic rate (Fig. 2d).

\section{Physiological responses of Corallina officinalis vs. Chondrus crispus}

Photosynthesis

Dark respiration rates $E_{\mathrm{k}}, P_{\max }$ and $\alpha$ of Corallina officinalis and Chondrus crispus were not significantly affected by $\mathrm{CO}_{2}$ concentration, but there was a significant main effect of time on $\alpha$ and respiration rate, a significant interaction between time and species with respect to $E_{\mathrm{k}}$ and $\alpha$, and a significant effect of species on $\alpha$ (Tables $2 \& 3$, Fig. 3). The interaction between time and species was due to the fact that $E_{\mathrm{k}}$ and photosynthetic efficiency of $C$. crispus were much higher and lower, respectively, after $88 \mathrm{~d}$ of exposure compared to the rates after $38 \mathrm{~d}$, which was likely a seasonal effect in response to higher temperatures. Photosynthetic efficiency of $C$. officinalis at the end of the experiment was higher than at the beginning, and was also higher than the photosynthetic efficiency of $C$. crispus after $88 \mathrm{~d}$. The $E_{\mathrm{k}}$ values of $C$. officinalis after $88 \mathrm{~d}$ tended to decrease with increasing $\mathrm{CO}_{2}$ concentration, but the trend was not significant (Pearson's $r=-0.567, p=0.056)$. In contrast, the $E_{\mathrm{k}}$ values of $C$. crispus were higher at the end of the experiment than at the beginning, regardless of $\mathrm{CO}_{2}$ concentration. 

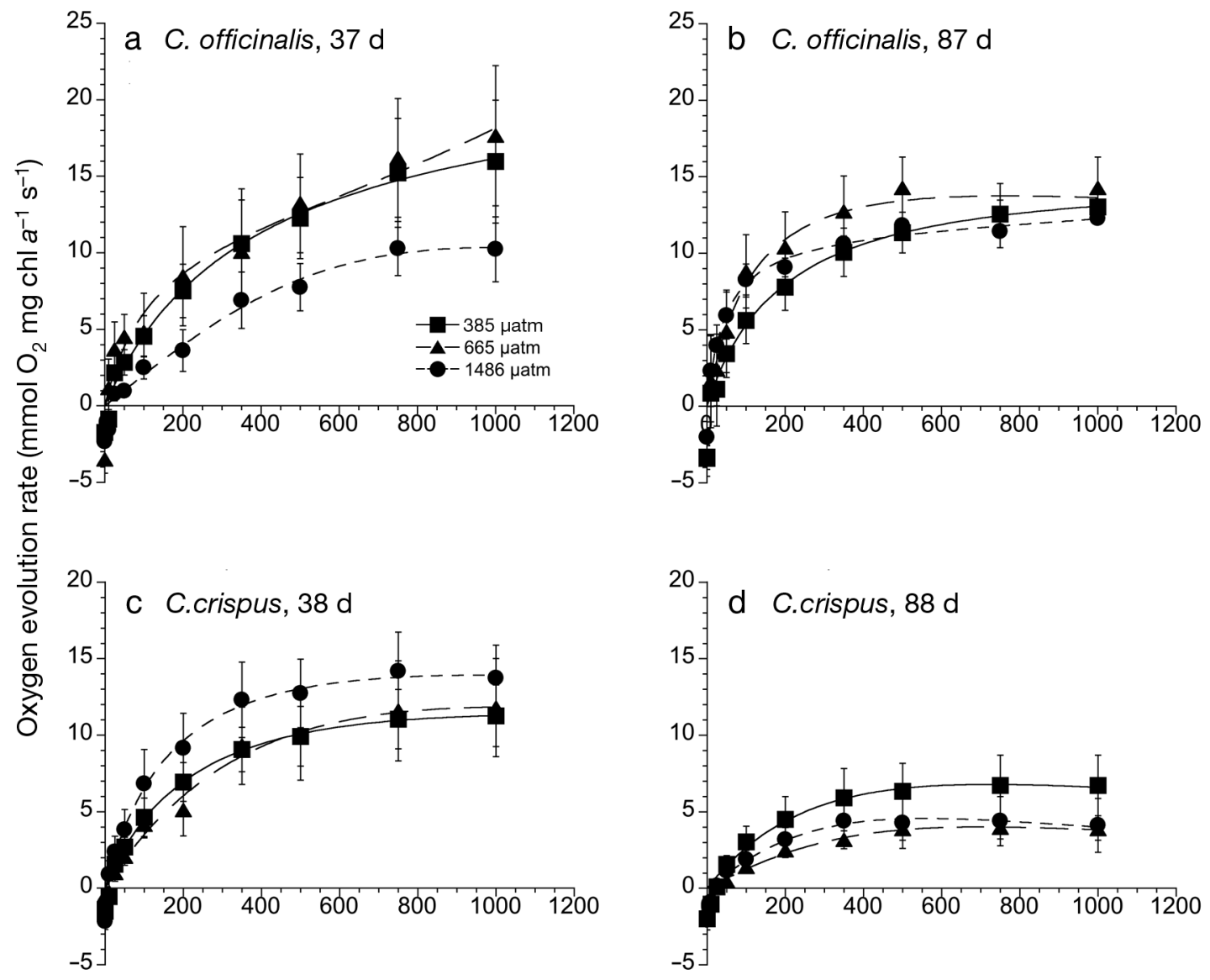

Light intensity ( $\mu \mathrm{mol}$ photons $\left.\mathrm{m}^{-2} \mathrm{~s}^{-1}\right)$

Fig. 3. Corallina officinalis and Chondrus crispus. Oxygen production as a function of light intensity in Corallina officinalis after (a) $37 \mathrm{~d}$ and (b) $87 \mathrm{~d}$, and in Chondrus crispus after (c) $38 \mathrm{~d}$ and (d) $88 \mathrm{~d}$ of exposure to $\mathrm{CO}_{2}$ treatments. Means \pm SE are shown

Table 2. Corallina officinalis and Chondrus crispus. Photosynthetic parameters (means \pm SE) measured after 37/38 and 87/88 d exposure to $\mathrm{CO}_{2}$ treatments. Parameters are based on oxygen evolution measurements at multiple light intensities ranging from 0 to $1000 \mu \mathrm{mol}$ photons $\mathrm{m}^{-2} \mathrm{~s}^{-1}$. $P_{\text {max }}$ : maximum photosynthetic rate, $E_{\mathrm{k}}$ : light saturation point, $\alpha$ : photosynthetic efficiency. nd: no data

\begin{tabular}{|c|c|c|c|c|c|}
\hline Species & $\begin{array}{l}\mathrm{CO}_{2} \text { level } \\
\quad(\mu \mathrm{atm})\end{array}$ & $\begin{array}{l}\text { Exposure } \\
\text { (d) }\end{array}$ & 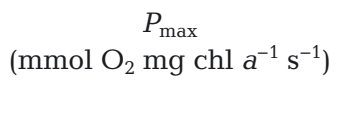 & $\begin{array}{c}E_{\mathrm{k}} \\
\left(\mu \mathrm{mol} \text { photons } \mathrm{m}^{-2} \mathrm{~s}^{-1}\right)\end{array}$ & $\begin{array}{c}\alpha \\
{\left[\mathrm{mmol} \mathrm{O}_{2}(\mathrm{mg} \mathrm{chl} \mathrm{a})^{-1}\right.} \\
\left.\left(\mu \mathrm{mol} \text { photons } \mathrm{m}^{-2}\right)\right]\end{array}$ \\
\hline \multirow[t]{6}{*}{ Corallina officinalis } & 385 & 37 & $16.4 \pm 4.2$ & $408 \pm 81$ & $0.046 \pm 0.015$ \\
\hline & 665 & 37 & $17.1 \pm 3.7$ & nd & $0.050 \pm 0.024$ \\
\hline & 1486 & 37 & $10.8 \pm 2.1$ & $396 \pm 23$ & $0.023 \pm 0.009$ \\
\hline & 385 & 87 & $13.1 \pm 1.5$ & $385 \pm 145$ & $0.107 \pm 0.071$ \\
\hline & 665 & 87 & $13.8 \pm 1.7$ & $165 \pm 46$ & $0.200 \pm 0.109$ \\
\hline & 1486 & 87 & $11.7 \pm 0.3$ & $93 \pm 70$ & $0.487 \pm 0.251$ \\
\hline \multirow[t]{6}{*}{ Chondrus crispus } & 385 & 38 & $11.3 \pm 2.0$ & $205 \pm 46$ & $0.066 \pm 0.018$ \\
\hline & 665 & 38 & $11.9 \pm 3.3$ & $280 \pm 112$ & $0.050 \pm 0.009$ \\
\hline & 1486 & 38 & $14.0 \pm 2.3$ & $203 \pm 62$ & $0.115 \pm 0.054$ \\
\hline & 385 & 88 & $6.9 \pm 2.0$ & $279 \pm 63$ & $0.033 \pm 0.012$ \\
\hline & 665 & 88 & $4.0 \pm 0.8$ & $321 \pm 97$ & $0.016 \pm 0.004$ \\
\hline & 1486 & 88 & $4.6 \pm 1.7$ & $208 \pm 31$ & $0.021 \pm 0.005$ \\
\hline
\end{tabular}




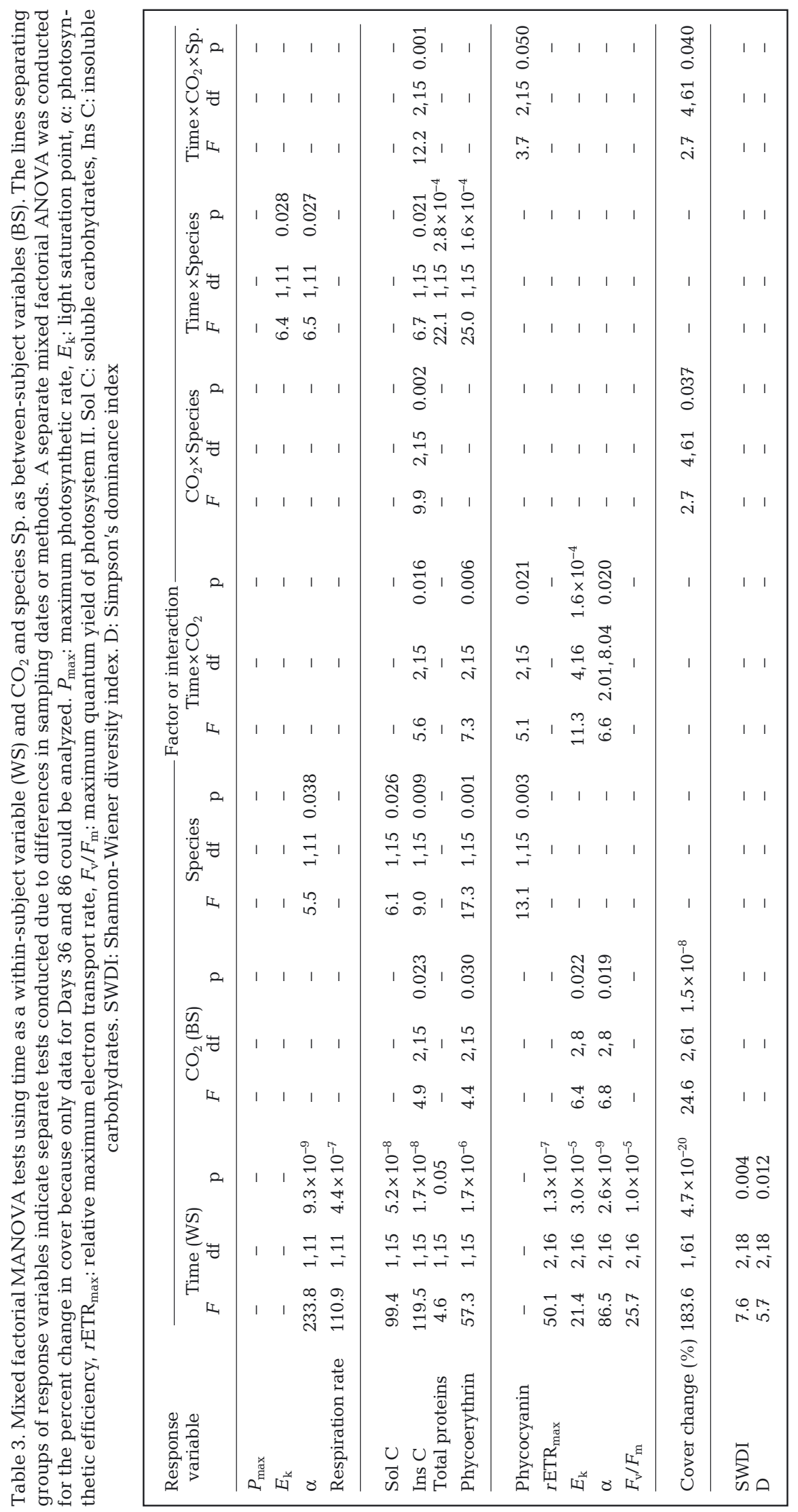

Concentration of phycobilins, soluble proteins, and carbohydrates

A mixed factorial MANOVA test using species and $\mathrm{CO}_{2}$ as betweensubject factors, time as a withinsubject factor, and soluble carbohydrates, insoluble carbohydrates, total protein, and phycobiliproteins (phycoerythrin and phycocyanin) as dependent variables showed a significant main effect of time on all variables except phycocyanin. There was a significant interactive effect between all factors on insoluble carbohydrates and phycocyanin, while total proteins were only significantly affected by an interaction between time and species. Both phycobilisomes were affected by an interaction between $\mathrm{CO}_{2}$ and time, but only phycoerythrin was affected by an interaction between time and species (Table 3 ).

The phycobiliprotein content in Corallina officinalis and Chondrus crispus was particularly affected by both time of exposure and $\mathrm{CO}_{2}$ treatment (Fig. 4a,b). While $35 \mathrm{~d}$ of exposure did not have a strong effect on phycobiliprotein content, the concentrations of both phycobiliproteins in $C$. crispus decreased with increasing $\mathrm{CO}_{2}$ level after $85 \mathrm{~d}$ of exposure to the treatments. For C. officinalis, the response was not as strong, but phycoerythrin increased in the $665 \mu \mathrm{atm} \mathrm{CO}_{2}$ treatment from Day 35 to 85, while the phycocyanin concentration was generally low in this treatment for both time measurements.

During the 3 mo experiment, the concentrations of total protein and soluble and insoluble carbohydrates in both species changed over time and depended on species or $\mathrm{CO}_{2}$ concentration (Fig. 5). In general, Chondrus crispus had higher levels of proteins and carbohydrates compared to Corallina officinalis after $35 \mathrm{~d}$, and the total amount of insoluble carbohydrates was elevated in 


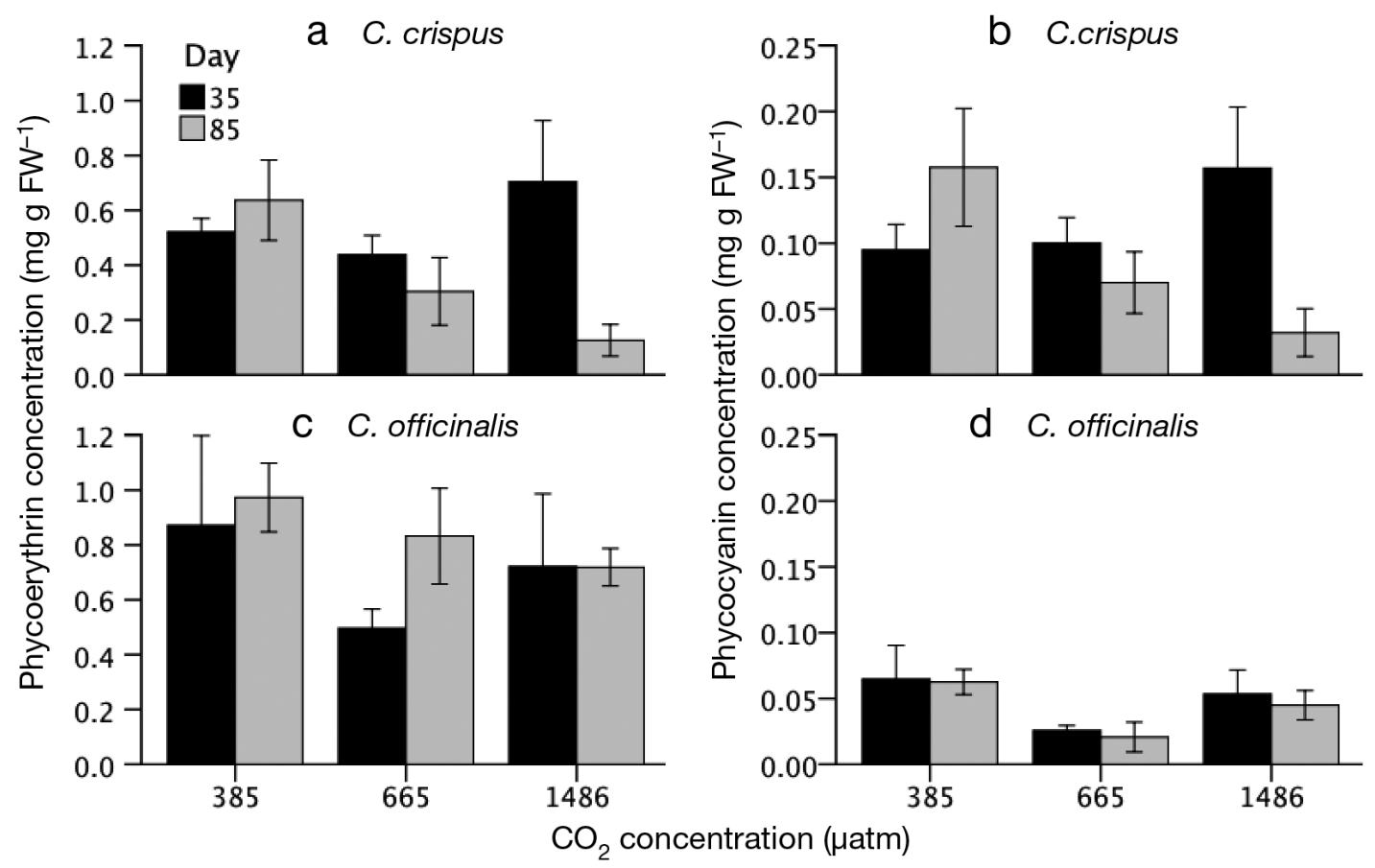

Fig. 4. Chondrus crispus and Corallina officinalis. Concentration of phycoerythrin and phycocyanin in C. crispus (a,b) and C. officinalis $(\mathrm{c}, \mathrm{d})$ after 35 and $85 \mathrm{~d}$ of exposure to $\mathrm{CO}_{2}$ treatments. FW: fresh weight. Means $\pm \mathrm{SE}$ are shown

the $2 \mathrm{CO}_{2}$ treatments compared to the ambient treatment. However, after longer exposure, there was a sharp decline in protein and carbohydrates (both soluble and insoluble) content in the 2 high$\mathrm{CO}_{2}$ treatments. This response may have been related to the combined stress of elevated temperature and $\mathrm{CO}_{2}$ during the warmest part of the summer (July). C. officinalis responded early to the $\mathrm{CO}_{2}$ treatments after $35 \mathrm{~d}$ of exposure by decreasing protein levels. After $85 \mathrm{~d}$, the protein concentrations in $C$. officinalis tissue increased in all treatments, but they did not differ significantly among $\mathrm{CO}_{2}$ treatments.

A discriminant analysis of the dependent variables was conducted for better interpretation of the mixed factorial multivariate MANOVA. The analysis after $35 \mathrm{~d}$ revealed only 1 factor that significantly discriminated the treatment groups $\left(\Lambda=0.067, \chi^{2}(25)=47.2\right.$, $\mathrm{p}=0.005)$ and explained $93.6 \%$ of the variance. However, the analysis after $85 \mathrm{~d}$ revealed 2 discriminant functions that explained 65.3 and $30.6 \%$ of the variance, respectively (canonical $\mathrm{R}^{2}=0.90$ and 0.81 respectively). These discriminant functions in combination significantly discriminated the treatment groups $\left(\Lambda=0.013, \chi^{2}(25)=63.5, p<0.001\right)$, and the second function further discriminated the treatment groups alone $\left(\Lambda=0.123, \chi^{2}(16)=30.4, p=0.016\right)$. The correlations between the discriminating functions

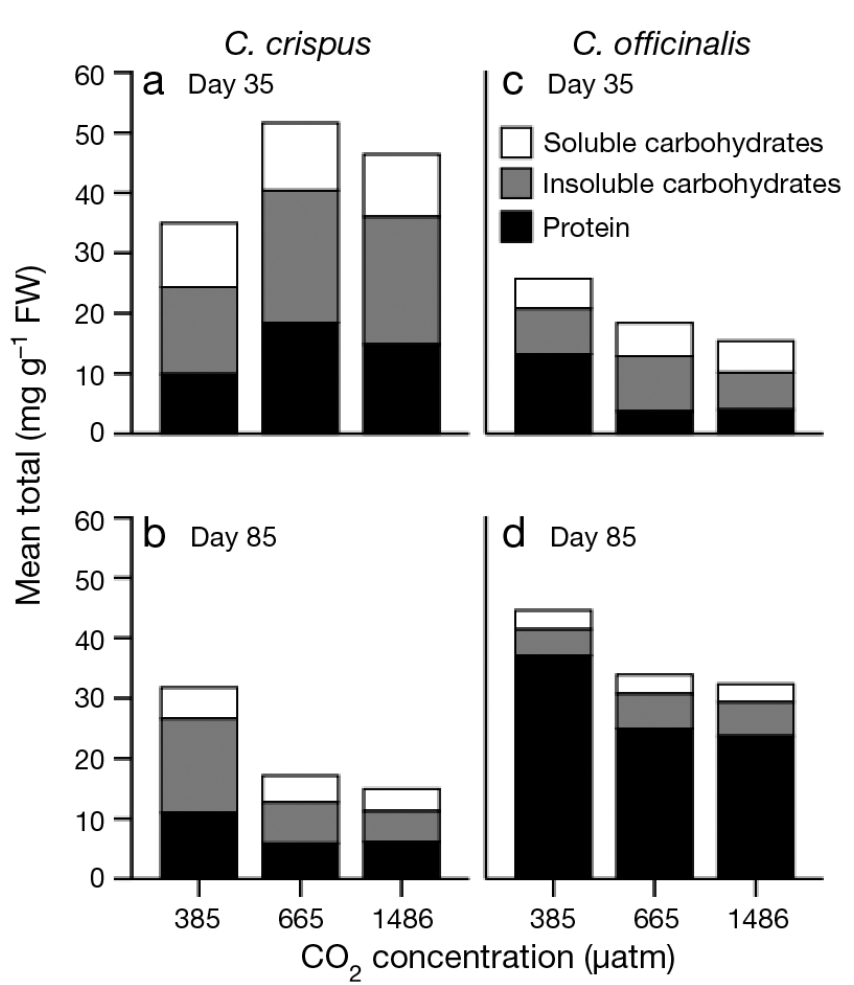

Fig. 5. Chondrus crispus and Corallina officinalis. Total carbohydrate (soluble and insoluble) and protein concentrations in C. crispus $(\mathrm{a}, \mathrm{b})$ and C. officinalis $(\mathrm{c}, \mathrm{d})$ thalli after $35 \mathrm{~d}(\mathrm{a}, \mathrm{c})$ and $85 \mathrm{~d}(\mathrm{~b}, \mathrm{~d})$ of exposure to 3 experimental $\mathrm{CO}_{2}$ treatments. FW: fresh weight 
and the variables showed that after $35 \mathrm{~d}$, all variables except phycoerythrin $(r=-0.05)$ loaded equally low $(r=0.29$ to 0.32$)$ on Function 1. After $85 d$, insoluble carbohydrates had the highest loading on Function 1 $(r=0.51)$, while phycoerythrin and proteins had the highest correlations with Function $2(\mathrm{r}=0.67, \mathrm{r}=$ 0.53 , respectively). The combined groups plots for both time periods are shown in Fig. 6 . The plot shows that after $35 \mathrm{~d}$, the first function discriminated between the control treatment and the elevated- $\mathrm{CO}_{2}$ treatments for both species, while after $85 \mathrm{~d}$, both functions strongly discriminated between the ambient- and elevated- $\mathrm{CO}_{2}$ groups for the 2 species. Overall, Fig. 6 demonstrates that time, $\mathrm{CO}_{2}$ concentration, and species had an effect on the protein, carbohydrate, and phycobiliprotein concentrations of the algae investigated.

\section{Community responses}

\section{Photochemistry}

A mixed factorial MANOVA with species (Chondrus crispus and Corallina officinalis) and $\mathrm{CO}_{2}$ level as between-subject factors, time of exposure as a within-subject factor, and $r \mathrm{ETR}_{\max }$ electron transport rate efficiency $(\alpha), E_{\mathrm{k}}$, and $F_{\mathrm{v}} / F_{\mathrm{m}}$ as dependent response variables indicated that there was a signif- icant effect of time on all 4 response variables, and a significant interactive effect between time and $\mathrm{CO}_{2}$ on $r \mathrm{ETR}_{\max }$ and $\alpha$ (Table 3). After $36 \mathrm{~d}$ of exposure to the treatments, all algae investigated (with the exception of Ulva spp., which only appeared at the end of the experiment) had higher $r \mathrm{ETR}_{\max }$ values in the ambient treatment than the 2 elevated$\mathrm{CO}_{2}$ treatments (Fig. 7). The lower $r$ ETR $\mathrm{max}_{\max }$ rates exhibited by algae grown in the elevated- $\mathrm{CO}_{2}$ treatments resulted from higher nonphotochemical quenching and therefore lower chlorophyll fluorescence yields (Fig. 8). However, by the end of the experiment, the $\mathrm{CO}_{2}$ effect on chlorophyll fluorescence was no longer visible. The $E_{\mathrm{k}}$ values did not show a strong response to $\mathrm{CO}_{2}$ after $36 \mathrm{~d}$ of exposure, but after $86 \mathrm{~d}$, the values were highest in the 665 uatm $\mathrm{CO}_{2}$ treatment for crustose coralline algae, C. crispus, and C. officinalis.

The response of $F_{\mathrm{v}} / F_{\mathrm{m}}$ was not significantly affected by $\mathrm{CO}_{2}$ (Table 3, Fig. 7). The mean $F_{\mathrm{v}} / F_{\mathrm{m}}$ of Chondrus crispus, Corallina officinalis, and Dumontia incrassata showed a negative trend with increasing $\mathrm{CO}_{2}$ after $36 \mathrm{~d}$, but the $F_{\mathrm{v}} / F_{\mathrm{m}}$ values recovered after $86 \mathrm{~d}$ in the $1486 \mu \mathrm{atm} \mathrm{CO}_{2}$ treatment for C. crispus and $C$. officinalis. The crustose coralline algae did now show a strong response after $36 \mathrm{~d}$. Ulva linza, which appeared later during the course of the experiment, had the lowest mean maximum quantum yield in the $665 \mu \mathrm{atm} \mathrm{CO}_{2}$ treatment.
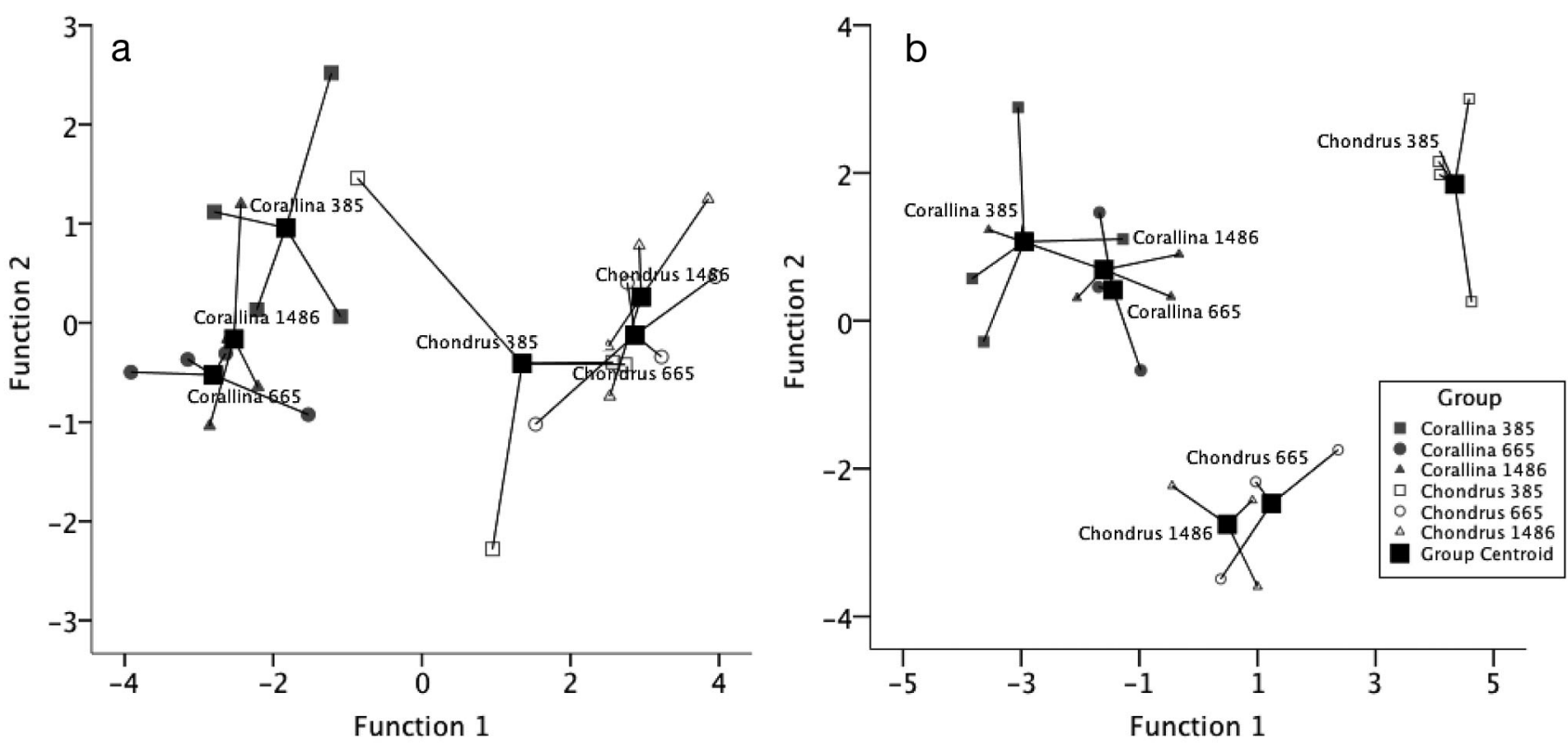

Fig. 6. Corallina officinalis and Chondrus crispus. Combined groups plots generated by discriminant analysis of carbohydrate (soluble and insoluble), protein, and phycobiliprotein concentrations in C. officinalis and C. crispus after (a) $35 \mathrm{~d}$ and (b) $85 \mathrm{~d}$ of exposure to $\mathrm{CO}_{2}$ treatments. The response variables were grouped based on species and $\mathrm{CO}_{2}$ treatment and the functions are canonical discriminant functions 

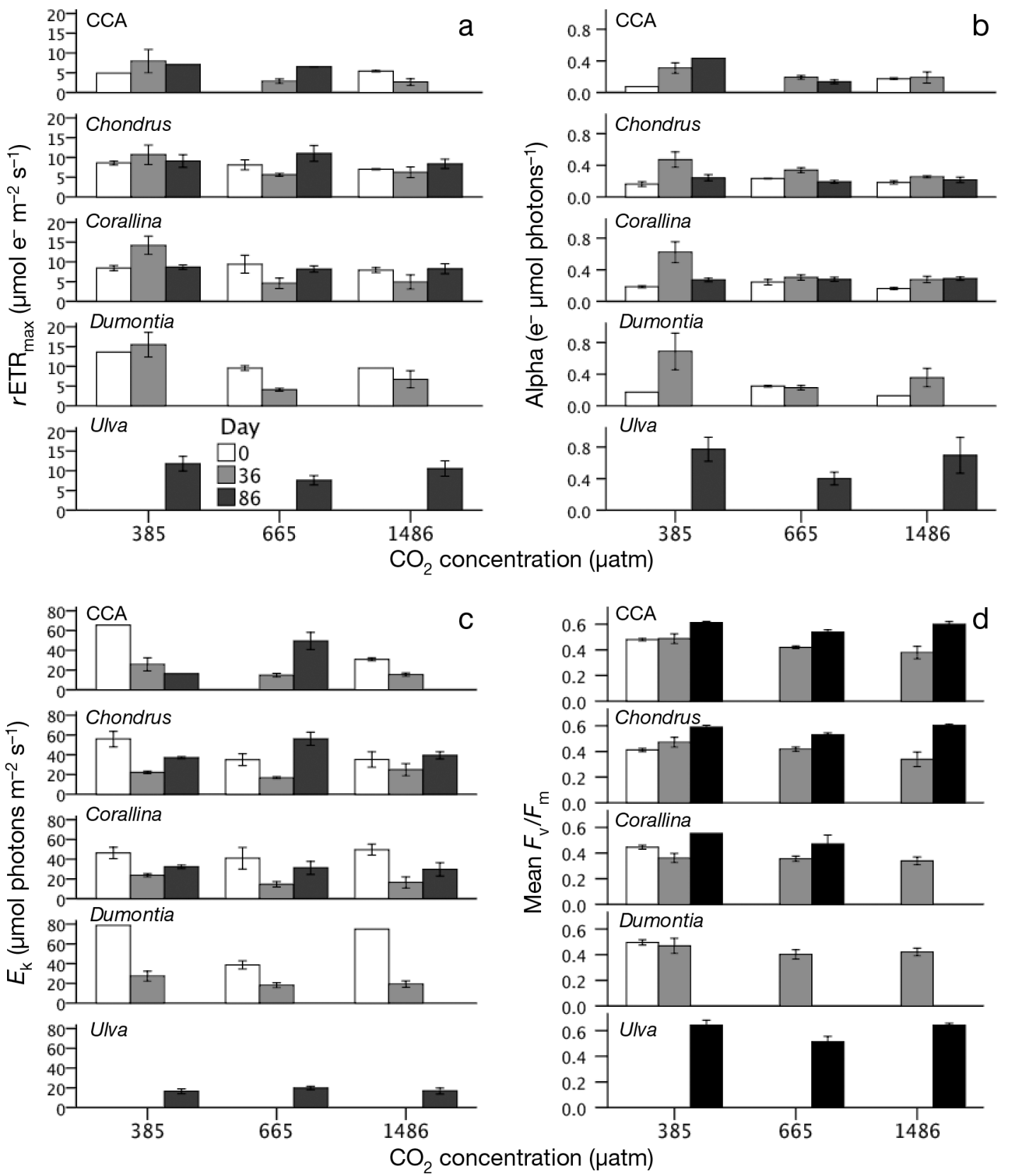

Fig. 7. Photochemical parameters for the 4 genera of macroalgae and the group of crustose coralline algae (CCA) present in the experimental communities based on chlorophyll fluorescence measurements at multiple light intensities ranging from 0 to $600 \mu \mathrm{mol}$ photons $\mathrm{m}^{-2} \mathrm{~s}^{-1}$. (a) Relative maximum electron $\left(\mathrm{e}^{-}\right)$transport rates $\left(r \mathrm{ETR}_{\max }\right)$, (b) electron transport efficiency (alpha), (c) light saturation points $\left(E_{\mathrm{k}}\right)$, and $(\mathrm{d})$ maximum quantum yield of photosystem II $\left(F_{\mathrm{v}} / F_{\mathrm{m}}\right)$ are shown for each species or algal group at Day 0,36, and 86 of the experiment. Means \pm SE are shown

Percent cover, diversity and dominance

Due to the relatively large size of our mesocosms and long experimental period, we were able to detect changes in macroalgal community structure in response to elevated $\mathrm{CO}_{2}$. Fig. 9 shows the mean percent cover of all algal species present in the ex- perimental communities. The total macroalgal cover increased over time in all treatments. Community diversity increased and dominance decreased over time (Tables $3 \& 4$ ), but neither was significantly affected by $\mathrm{CO}_{2}$ treatment. When considering individual species, the percent cover of Ulva linza, which appeared in all treatments at the end of the experi- 

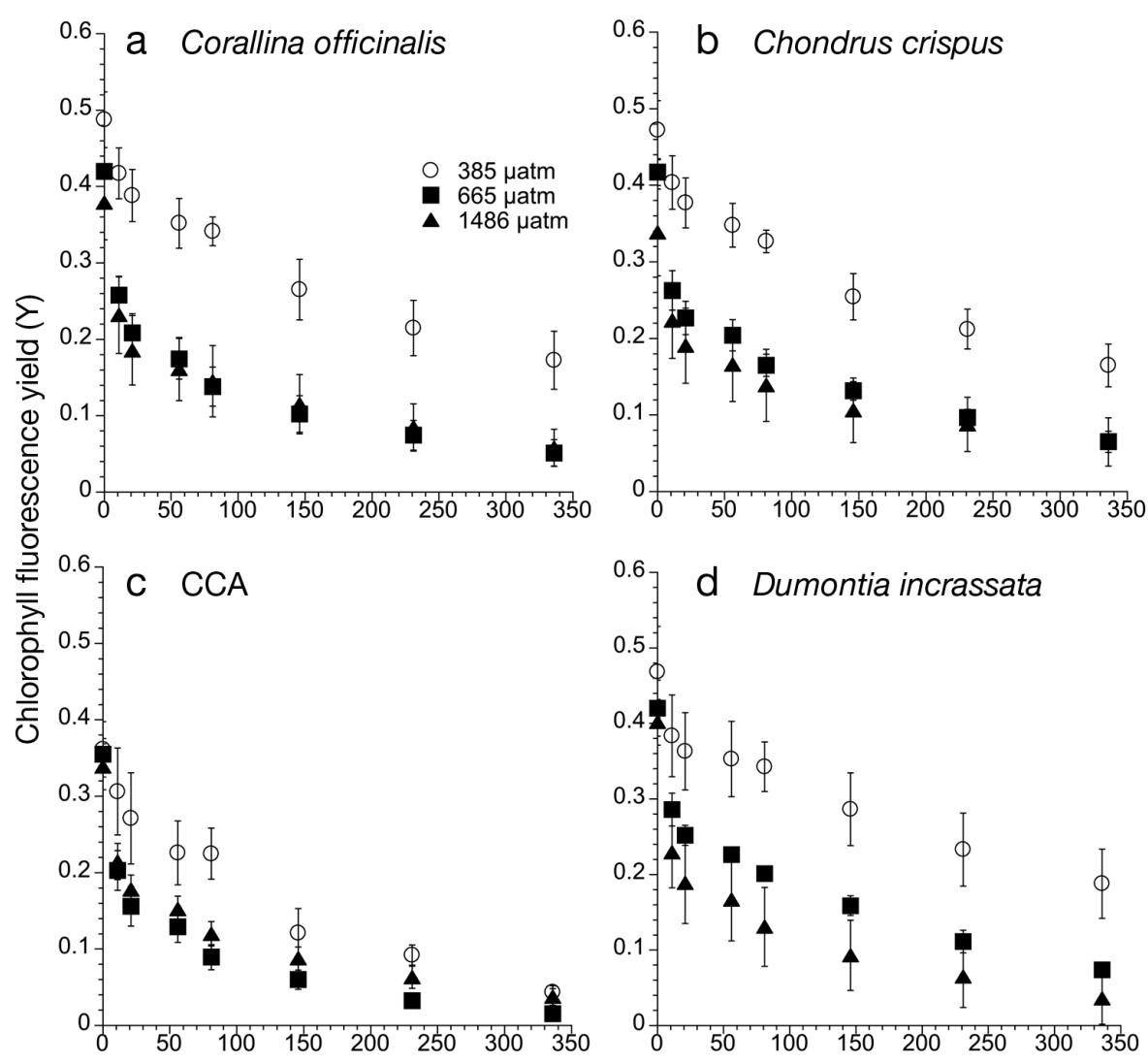

Fig. 8. Chlorophyll fluorescence yield as a function of light intensity for 4 species and the group of crustose coralline algae (CCA) investigated: (a) Corallina officinalis, (b) Chondrus crispus, (c) CCA, and (d) Dumontia incrassata after 36 d of $\mathrm{CO}_{2}$ treatments, and (e) Ulva linza, which appeared late in the experiment. Means $\pm \mathrm{SE}$ are shown
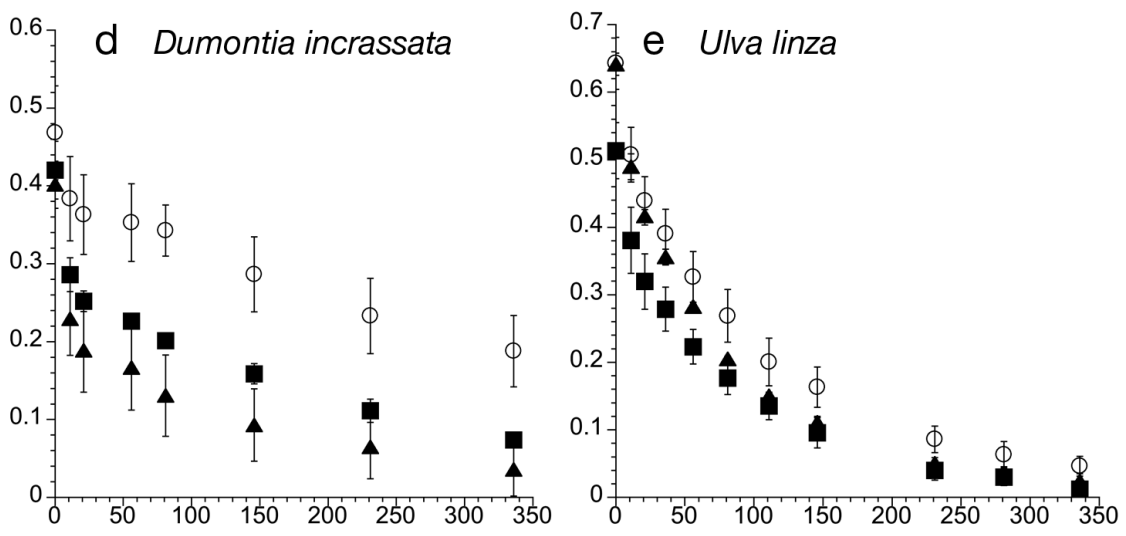

Light intensity ( $\mu \mathrm{mol}$ photons $\mathrm{m}^{-2} \mathrm{~s}^{-1}$ )

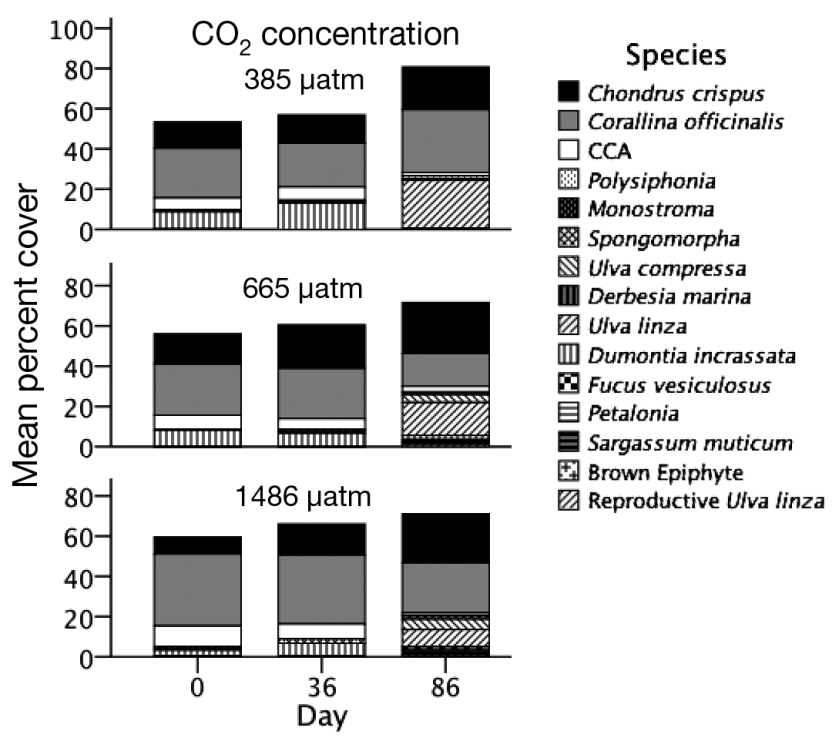

Fig. 9. Mean percent cover of all species of algae present in the experimental communities at Day 0,36, and 86 for each $\mathrm{CO}_{2}$ concentration. CCA: crustose coralline algae

ment, was significantly negatively correlated to $\mathrm{CO}_{2}$ concentration (Pearson's $r=-0.381, \mathrm{p}=0.033$; Fig. 9). When the relative percent cover with respect to the calcifiers (Corallina officinalis and crustose coralline
Table 4. Shannon-Wiener diversity index and Simpson's reciprocal dominance index $(1 / \mathrm{D})$ for the macroalgal communities exposed to $\mathrm{CO}_{2}$ treatments at Days 0,36 , and 86. Mean \pm SE

\begin{tabular}{|cccc|}
\hline Day & $\begin{array}{c}\mathrm{CO}_{2} \text { conc. } \\
(\mu \mathrm{atm})\end{array}$ & $\begin{array}{c}\text { Shannon-Wiener } \\
\text { diversity index }\end{array}$ & $1 / \mathrm{D}$ \\
\hline 0 & 385 & $0.89 \pm 0.07$ & $0.88 \pm 0.02$ \\
& 665 & $0.82 \pm 0.04$ & $0.84 \pm 0.03$ \\
& 1486 & $0.85 \pm 0.08$ & $0.81 \pm 0.03$ \\
36 & 385 & $0.87 \pm 0.09$ & $0.85 \pm 0.03$ \\
& 665 & $0.93 \pm 0.07$ & $0.81 \pm 0.04$ \\
86 & 1486 & $0.91 \pm 0.06$ & $0.78 \pm 0.03$ \\
& 385 & $1.03 \pm 0.07$ & $0.73 \pm 0.03$ \\
& 665 & $1.09 \pm 0.06$ & $0.78 \pm 0.03$ \\
& 1486 & $1.09 \pm 0.08$ & $0.79 \pm 0.04$ \\
\hline
\end{tabular}

algae) and the prevalent noncalcifying red alga Chondrus crispus are considered, a $\mathrm{CO}_{2}$ effect is also present. Fig. 10 shows, quantitatively and qualitatively, the percent change in cover over time for these 3 taxa. A mixed factorial ANOVA test indicated that there were significant main effects of time and $\mathrm{CO}_{2}$ level as well as an interaction between all 3 independent factors (Table 3). C. crispus increased in 


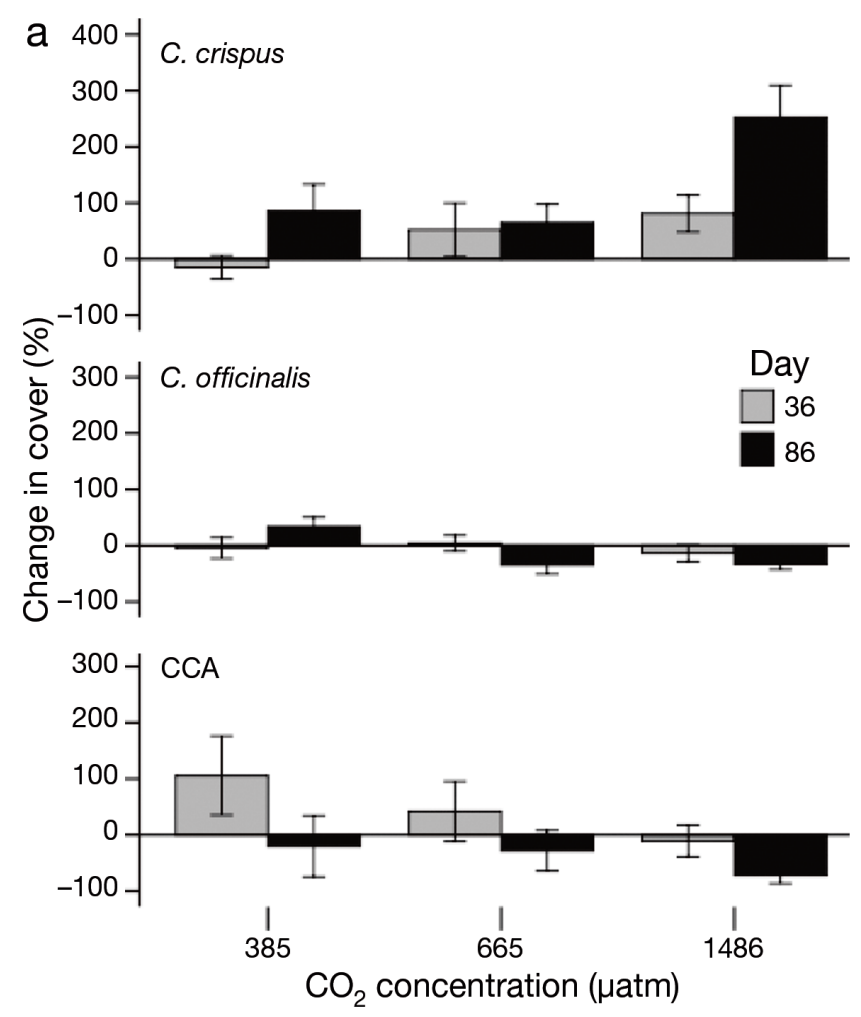

b

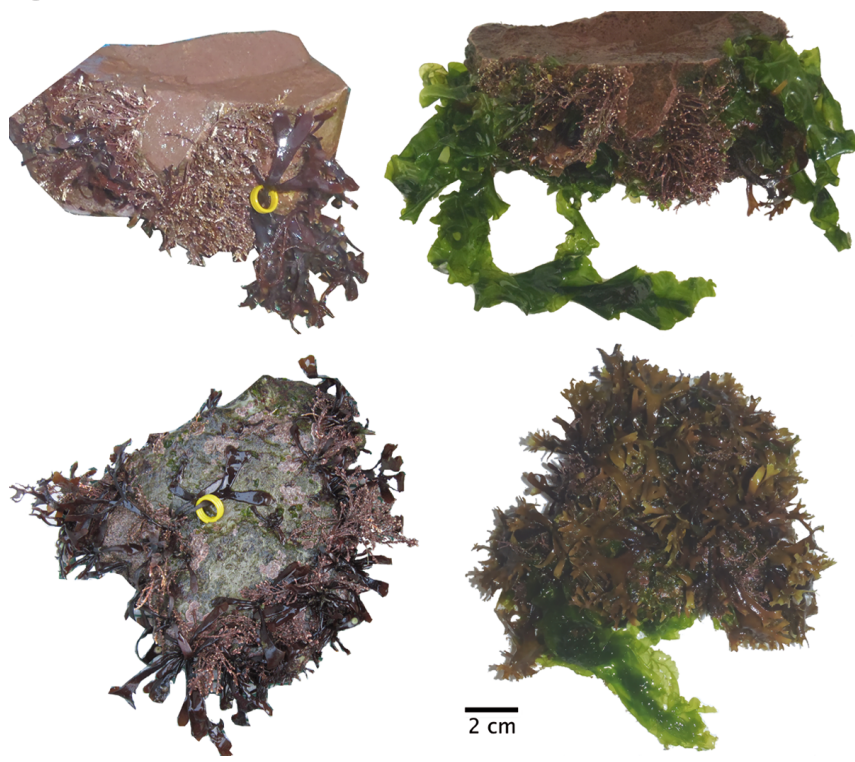

Fig. 10. (a) Change in cover (means $\pm \mathrm{SE}$ ) with respect to initial value after 36 and $86 \mathrm{~d}$ exposure to $\mathrm{CO}_{2}$ treatments for Chondrus crispus, Corallina officinalis, and crustose coralline algae (CCA). (b) Examples of communities from the ambient- $\mathrm{CO}_{2}$ (above) and high- $\mathrm{CO}_{2}$ (below) treatments at Days 0 (left) and 86 (right). In both communities, Ulva linza appeared after $86 \mathrm{~d}$, but it is clear in the ambient- $\mathrm{CO}_{2}$ treatment that $C$. officinalis and $C$. crispus maintain their respective cover, while in the high- $\mathrm{CO}_{2}$ treatment, $C$. crispus encroaches on the space occupied by C. officinalis after $86 \mathrm{~d}$ all treatments over time, but the change in cover was greatest in the $1486 \mu$ atm $\mathrm{CO}_{2}$ treatment after $86 \mathrm{~d}$. In contrast, the calcifying $C$. officinalis decreased in cover in the $1486 \mu$ atm $\mathrm{CO}_{2}$ treatment after just $36 \mathrm{~d}$ and in both elevated- $\mathrm{CO}_{2}$ treatments after $86 \mathrm{~d}$, while the percent cover increased in the ambient treatment. The crustose coralline algae showed the highest decrease in cover at the highest- $\mathrm{CO}_{2}$ treatment after $86 \mathrm{~d}$ due to overgrowth by the noncalcifying species.

\section{DISCUSSION}

The physiological responses of the coexisting Corallina officinalis and Chondrus crispus to elevated $\mathrm{CO}_{2}$ are complex and shed some light on how competitive interactions may shift between calcifying and noncalcifying macroalgae under future $\mathrm{CO}_{2}$ conditions. The most striking responses were the decreased growth rates and inorganic carbon in the C. officinalis skeleton. Such responses in C. officinalis have been previously shown (Hofmann et al. 2012), but we also present net calcification rates, which showed a parabolic relationship to $\mathrm{CO}_{2}$ concentration (the highest rate was at 665 uatm $\mathrm{CO}_{2}$ ). Such a calcification response has been reported for another coralline algae, Neogoniolithon sp. (Ries et al. 2009). Those authors attributed the higher calcification rates at $\mathrm{pCO}_{2}$ concentrations between 600 and $1100 \mu \mathrm{atm}$ to higher rates of photosynthesis providing more energy for $\mathrm{pH}$ regulation. In fact, evidence of $\mathrm{CO}_{2}$ fertilization of photosynthesis in calcifying macroalgae is weak. Gao \& Zheng (2010) actually found a decrease in photosynthetic rates of Corallina sessilis at 1000 ppmv $\mathrm{CO}_{2}$ compared to $380 \mathrm{ppmv}$, and Hofmann et al. (2012) and Cornwall et al. (2012) showed no significant differences in maximum photosynthetic rates of $C$. officinalis at $\mathrm{CO}_{2}$ concentrations $>1300$ uatm.

We measured the highest maximum photosynthesis rate and calcification rate in algae grown in the $665 \mu$ atm $\mathrm{CO}_{2}$, suggesting that moderately high $\mathrm{CO}_{2}$ concentrations can stimulate photosynthesis and calcification to a limited extent. However, this stimulation of calcification rates does not necessarily result in a higher net deposition of $\mathrm{CaCO}_{3}$, as skeletal inorganic carbon of Corallina officinalis decreased with increasing $\mathrm{CO}_{2}$ concentration and increasing net calcification rate (above a threshold of $77 \%$ inorganic carbon). These results are consistent with Hofmann et al. (2012), who found that the area of deposited $\mathrm{CaCO}_{3}$ between $C$. officinalis cells decreased under 
elevated $\mathrm{CO}_{2}$. The reason for the discrepancy between calcification rates and skeletal inorganic carbon content could be higher dissolution rates in the dark. Martin \& Gattuso (2009) found significantly higher dissolution rates of dead Lithothamnion cabiochae thalli under elevated $\mathrm{CO}_{2}(700 \mathrm{ppm})$ compared to ambient concentrations (400 ppm), but found no significant difference in net calcification rates after $1 \mathrm{mo}$ of exposure to the experimental $\mathrm{CO}_{2}$ treatments. Similar discrepancies between net calcification and dissolution rates have been found for some corals and mollusks (Rodolfo-Metalpa et al. 2011). In the present study, the stimulation of calcification at moderate $\mathrm{CO}_{2}$ concentrations allowed C. officinalis to maintain its inorganic skeleton despite (most likely) higher dissolution rates in the dark. However, there is a threshold $\mathrm{CO}_{2}$ level beyond which calcification and photosynthesis are no longer able to maintain ambient deposition rates of $\mathrm{CaCO}_{3}$, resulting in a less calcified skeleton. This threshold must lie somewhere between 1000 and 1400 ratm $\mathrm{CO}_{2}$ for temperate coralline macroalgae, based on the following: previously reported calcification rates of coralline algae under elevated $\mathrm{CO}_{2}$ concentrations (Anthony et al. 2008, Martin \& Gattuso 2009, Ries et al. 2009, Gao \& Zheng 2010), the results of the present study, and the evidence that photosynthetic rates and efficiency in Corallina spp. are decreased under $\mathrm{CO}_{2}$ concentrations beyond $1000 \mu \mathrm{atm}$ (Gao \& Zheng 2010, Hofmann et al. 2012).

While Corallina officinalis is able to maintain a heavily calcified skeleton under moderately elevated $\mathrm{CO}_{2}$, the energy cost of elevating calcification rates may still have an effect on the competitive success of this species. For example, growth rates and protein levels were both lower after $35 \mathrm{~d}$ of exposure to 665 patm $\mathrm{CO}_{2}$, while the calcification rate was elevated. In contrast, the noncalcifying Chondrus crispus elevated its cellular protein and carbohydrate content after $35 \mathrm{~d}$ of exposure. In benthic calcifying animals, such an energy trade-off between net calcification rates and other physiological processes has been postulated (Findlay et al. 2011). Those authors found that net calcification rates can be maintained or even elevated under high $\mathrm{CO}_{2}$ conditions, but at costs such as increased metabolism or lower predation-avoidance response. The presence of protective organic or tissue layers is also a significant factor affecting the responses of different calcifying organisms (RodolfoMetalpa et al. 2011). Therefore, an organism's ability to cope with the changes associated with ocean acidification will depend on its ability to obtain additional resources needed to supply the high energy de- mands of maintaining calcification. These changes in energy allocation are likely to have contributed to the community shift observed in our study where the noncalcifying $C$. crispus increased while the calcifying $C$. officinalis decreased in cover at both elevated $\mathrm{CO}_{2}$ levels. The observed community shift cannot be explained simply by changes in photosynthetic rates, as C. crispus showed only a marginal increase in oxygen production (nonsignificant at the $95 \%$ CI level) at the highest- $\mathrm{CO}_{2}$ treatment after $35 \mathrm{~d}$, and no change relative to the ambient level after $85 \mathrm{~d}$. The photosynthetic response of C. crispus is not surprising, as many authors have already shown that noncalcifying algae do not always respond to elevated $\mathrm{CO}_{2}$ by increasing photosynthesis, and in fact some even decrease their photosynthetic rates (GarcíaSánchez et al. 1994, Mercado et al. 1999, Gordillo et al. 2001, Zou 2005). Therefore, nutrient availability is important for when interpreting the responses of algae to elevated $\mathrm{CO}_{2}$.

Several of the responses measured showed sensitivity to the interaction between exposure time and $\mathrm{CO}_{2}$ concentration, suggesting that seasonal fluctuations in inorganic nutrient supply also influence the effects of $\mathrm{CO}_{2}$ on marine calcifying algae. At the beginning of our experiment, nitrate concentrations were high but decreased steadily during the first $40 \mathrm{~d}$ of the experiment. Then they slowly began to increase again but only to $40 \%$ of the initial level (data not shown). Furthermore, water temperature constantly increased during the summer season and reached maximum levels at the end of the experiment. The combination of relatively low nitrate availability and high temperature could explain the generally positive physiological responses to elevated $\mathrm{CO}_{2}$ concentrations in C. crispus at the end of the experiment. Gordillo et al. (2001) reported the significance of nitrogen availability in the response of the noncalcifying green alga Ulva rigida to elevated $\mathrm{CO}_{2}$ concentrations. Nitrogen-limited algae exposed to elevated $\mathrm{CO}_{2}$ concentrations showed increased growth rates but decreased net photosynthesis and soluble protein concentration. We saw a similar response in C. crispus after $85 \mathrm{~d}$ of exposure to elevated $\mathrm{CO}_{2}$ concentrations when nitrate levels were much lower than during the first $35 \mathrm{~d}$. The evidence from Gordillo et al. (2001) and the changes in physiological responses of C. crispus over time in our study support the notion that noncalcifying algae differ in their response to $\mathrm{CO}_{2}$ depending on external energy availability. Therefore, in areas exposed to the combination of elevated $\mathrm{CO}_{2}$ and eutrophication, changes in community structure between the coverage of calci- 
fiers and noncalcifiers could be amplified. Such a response has already been shown in a kelp understory, where turf algae expanded at the expense of calcifiers under elevated $\mathrm{CO}_{2}$ and nutrient conditions (Russell et al. 2009).

Our results indicate that elevated surface-seawater $\mathrm{CO}_{2}$ concentrations reachable within the next 100 to 200 yr could change the structure of temperate intertidal macroalgae communities containing dominant calcifying macroalgae such as Corallina spp. The observed changes in community structure would have important ecological implications. C. officinalis often grows in areas with strong currents and wave action, and serves as a habitat and buffer for meiofauna and substrate for other algae (Dommasnes 1968). With the decrease in abundance or even disappearance of this species, many other algae would lose their habitats and substrata for growth, while changes in carbohydrate content of the different macroalgal species would change the nutritional content and palatability of the algae for grazers.

The rapid increase in $\mathrm{CO}_{2}$ concentrations applied to our treatments and in almost all ocean acidification studies is often considered unrealistic. However, the observed changes in community structure are consistent with the observations of other authors who have investigated competition between calcifiers and noncalcifiers that have been exposed to naturally different $\mathrm{CO}_{2}$ concentrations for a long period (at least decades). For example, Porzio et al. (2011) report a significant reduction of calcitic macroalgae cover and the dominance of a few noncalcifying species, and Martin et al. (2008) report a lower abundance of calcifying seagrass epiphytes in areas with naturally elevated $\mathrm{CO}_{2}$ concentrations resulting from submerged volcanic vents. These observations are similar to our results, in that both highmagnesium calcite-depositing taxa (Corallina officinalis and crustose coralline algae) decreased in cover in both elevated- $\mathrm{CO}_{2}$ treatments, while Chondrus crispus cover increased the most in the highest- $\mathrm{CO}_{2}$ treatment. Our study adds to the evidence that crustose coralline algae are particularly susceptible to ocean acidification (Anthony et al. 2008, Jokiel et al. 2008, Kuffner et al. 2008, Martin et al. 2008, Büdenbender et al. 2011).

In conclusion, our study has added to the limited pool of long-term mesocosm experiments and contributes to increasing evidence that elevated surfaceseawater $\mathrm{CO}_{2}$ concentration will affect community composition of temperate rocky-shore macroalgae communities by altering the competitive relationship between calcifiers and noncalcifiers.
Acknowledgements. We thank the scientists and staff at the Wadden Sea Station of the Alfred-Wegener Institute for Polar and Marine Research for their support and contributions to this project, particularly Dr. R. Asmus, P. Kadel, R. Magens, B. Hussel, M. Ludwig-Schweikert, T. Romanova, M. Klett, and R. Gerrits. Funding for this project was provided by the German Federal Ministry of Education and Research (BMBF) through the cooperative research project Biological Impacts of Ocean Acidification (BIOACID).

\section{LITERATURE CITED}

Akioka H, Baba M, Masaki T, William Johansen H (1999) Rocky shore turfs dominated by Corallina (Corallinales, Rhodophyta) in northern Japan. Phycol Res 47:199-206

Andria J, Vergara J, Perez-Llorens JL (1999) Biochemical responses and photosynthetic performance of Gracilaria sp. (Rhodophyta) from Cádiz, Spain, cultured under different inorganic carbon and nitrogen levels. Eur J Phycol 34:497-504

Anthony KRN, Kline DI, Diaz-Pulido G, Dove S, HoeghGuldberg O (2008) Ocean acidification causes bleaching and productivity loss in coral reef builders. Proc Natl Acad Sci USA 105:17442-17446

Bak RPM (1976) The growth of coral colonies and the importance of crustose coralline algae and burrowing sponges in relation with carbonate accumulation. Neth J Sea Res 10:285-337

Barbarino E, Lourenço SO (2005) An evaluation of methods for extraction and quantification of protein from marine macro-and microalgae. J Appl Phycol 17:447-460

$>$ Beer S, Eshel A (1985) Determining phycoerythrin and phycocyanin concentrations in aqueous crude extracts of red algae. Mar Freshw Res 36:785-792

Bindoff, NL, Willebrand J, Artale V, Cazenave A and others (2007) Observations: oceanic climate change and sea level. In: Climate change 2007: the physical science Basis. Contribution of Working Group I to the Fourth Assessment Report of the Intergovernmental Panel on Climate Change. Solomon S, Qin D, Manning D, Chen Z and others (eds). Cambridge University Press, Cambridge

Bradford MM (1976) A rapid and sensitive method for the quantitation of microgram quantities of protein utilizing the principle of protein-dye binding. Anal Biochem 72: 248-254

> Büdenbender J, Riebesell U, Form A (2011) Calcification of the Arctic coralline red algae Lithothamnion glaciale in response to elevated $\mathrm{CO}_{2}$. Mar Ecol Prog Ser 441:79-87

> Caldeira K, Wickett ME (2003) Anthropogenic carbon and ocean $\mathrm{pH}$. Nature 425:365

> Caldeira K, Wickett ME (2005) Ocean model predictions of chemistry changes from carbon dioxide emissions to the atmosphere and ocean. J Geophys Res 110:1-12

> Cornwall CE, Hepburn CD, Pritchard D, Currie KI, McGraw CM, Hunter KA, Hurd CL (2012) Carbon-use strategies in macroalgae: differential responses to lowered $\mathrm{pH}$ and implications for ocean acidification. J Phycol 48:137-144

Coull BC, Wells JBJ (1983) Refuges from fish predation: experiments with phytal meiofauna from the New Zealand rocky intertidal. Ecology 64:1599-1609

Dommasnes A (1968) Variations in the meiofauna of Corallina officinalis L. with wave exposure. Sarsia 34:117-124 
Eilers PHC, Peeters JCH (1988) A model for the relationship between light intensity and the rate of photosynthesis in phytoplankton. Ecol Modell 42:199-215

Eriksson BK, Rubach A, Hillebrand H (2006) Biotic habitat complexity controls species diversity and nutrient effects on net biomass production. Ecology 87:246-254

Fabricius KE, Langdon C, Uthicke S, Humphrey C and others (2011) Losers and winners in coral reefs acclimatized to elevated carbon dioxide concentrations. Nat Clim Change 1:165-169

Fabry VJ (2008) Marine calcifiers in a high- $\mathrm{CO}_{2}$ ocean. Science 320:1020-1022

> Findlay HS, Wood HL, Kendall MA, Spicer JI, Twitchett RJ, Widdicombe $\mathrm{S}$ (2011) Comparing the impact of high $\mathrm{CO}_{2}$ on calcium carbonate structures in different marine organisms. Mar Biol Res 7:565-575

> Gao K, Zheng Y (2010) Combined effects of ocean acidification and solar UV radiation on photosynthesis, growth, pigmentation and calcification of the coralline alga Corallina sessilis (Rhodophyta). Glob Change Biol 16: 2388-2398

Gao K, Aruga Y, Asada K, Ishihara T, Akano T, Kiyohara M (1991) Enhanced growth of the red alga Porphyra yezoensis Ueda in high $\mathrm{CO}_{2}$ concentrations. J Appl Phycol 3: 355-362

Gao K, Aruga Y, Asada K, Kiyohara M (1993) Influence of enhanced $\mathrm{CO}_{2}$ on growth and photosynthesis of the red algae Gracilaria sp. and G. chilensis. J Appl Phycol 5: 563-571

García-Sánchez MJ, Fernández JA, Niell X (1994) Effect of inorganic carbon supply on the photosynthetic physiology of Gracilaria tenuistipitata. Planta 194:55-61

Gibbons MJ, Griffiths CL (1986) A comparison of macrofaunal and meiofaunal distribution and standing stock across a rocky shore, with an estimate of their productivities. Mar Biol 93:181-188

Gordillo FJ, Niell FX, Figueroa FL (2001) Non-photosynthetic enhancement of growth by high $\mathrm{CO}_{2}$ level in the nitrophilic seaweed Ulva rigida C. Agardh (Chlorophyta). Planta 213:64-70

> Hall-Spencer JM, Rodolfo-Metalpa R, Martin S, Ransome E and others (2008) Volcanic carbon dioxide vents show ecosystem effects of ocean acidification. Nature 454: 96-99

> Hepburn CD, Pritchard DW, Cornwall CE, McLeod RJ, Beardall J, Raven JA, Hurd CL (2011) Diversity of carbon use strategies in a kelp forest community: implications for a high $\mathrm{CO}_{2}$ ocean. Glob Change Biol 17: 2488-2497

> Hofmann LC, Yildiz G, Hanelt D, Bischof K (2012) Physiological responses of the calcifying rhodophyte Corallina officinalis (L.) to future $\mathrm{CO}_{2}$ levels. Mar Biol 159: 783-792

Israel A, Hophy M (2002) Growth, photosynthetic properties and Rubisco activities and amounts of marine macroalgae grown under current and elevated seawater $\mathrm{CO}_{2}$ concentrations. Glob Change Biol 8:831-840

> Jenkins SR, Hawkins SJ, Norton TA (1999) Direct and indirect effects of a macroalgal canopy and limpet grazing in structuring a sheltered inter-tidal community. Mar Ecol Prog Ser 188:81-92

Jokiel PL, Rodgers KS, Kuffner IB, Andersson AJ, Cox EF, Mackenzie FT (2008) Ocean acidification and calcifying reef organisms: a mesocosm investigation. Coral Reefs 27:473-483
Kochert G (1978) Carbohydrate determination by the phenol sulfuric acid method. In: Hellebust JA, Craigie JS (eds) Handbook of phycological methods: physiological and biochemical methods. Cambridge University Press, Cambridge, p 95-98

Kohler KE, Gill SM (2006) Coral Point Count with Excel extensions (CPCe): a Visual Basic program for the determination of coral and substrate coverage using random point count methodology. Comput Geosci 32: 1259-1269

Kroeker KJ, Kordas RL, Crim RN, Singh GG (2010) Metaanalysis reveals negative yet variable effects of ocean acidification on marine organisms. Ecol Lett 13: 1419-1434

Kübler JE, Johnston AM, Raven JA (1999) The effects of reduced and elevated $\mathrm{CO}_{2}$ and $\mathrm{O}_{2}$ on the seaweed Lomentaria articulata. Plant Cell Environ 22:1303-1310

Kuffner IB, Andersson AJ, Jokiel PL, Rodgers KS, Mackenzie FT (2008) Decreased abundance of crustose coralline algae due to ocean acidification. Nat Geosci 1: $114-117$

> Littler MM, Littler DS (1984) Relationships between macroalgal functional form groups and substrata stability in a subtropical rocky-intertidal system. J Exp Mar Biol Ecol 74:13-34

Lubchenco J (1978) Plant species diversity in a marine intertidal community: importance of herbivore food preference and algal competitive abilities. Am Nat 112: 23-39

Lubchenco J, Menge BA (1978) Community development and persistence in a low rocky intertidal zone. Ecol Monogr 48:67-94

> Martin S, Gattuso JP (2009) Response of Mediterranean coralline algae to ocean acidification and elevated temperature. Glob Change Biol 15:2089-2100

- Martin S, Rodolfo-Metalpa R, Ransome E, Rowley S, Buia MC, Gattuso JP, Hall-Spencer J (2008) Effects of naturally acidified seawater on seagrass calcareous epibionts. Biol Lett 4:689-692

> Mercado JM, Javier F, Gordillo L, Xavier Niell F, Figueroa FL (1999) Effects of different levels of $\mathrm{CO}_{2}$ on photosynthesis and cell components of the red alga Porphyra leucosticta. J Appl Phycol 11:455-461

Orr JC, Fabry VJ, Aumont O, Bopp L and others (2005) Anthropogenic ocean acidification over the twenty-first century and its impact on calcifying organisms. Nature 437:681-686

> Paine RT, Vadas RT (1969) Calorific values of benthic marine algae and their postulated relation to invertebrate food preference. Mar Biol 4:79-86

Porzio L, Buia MC, Hall-Spencer JM (2011) Effects of ocean acidification on macroalgal communities. J Exp Mar Biol Ecol 400:278-287

Ries JB (2009) Effects of secular variation in seawater $\mathrm{Mg} / \mathrm{Ca}$ ratio (calcite-aragonite seas) on $\mathrm{CaCO}_{3}$ sediment production by the calcareous algae Halimeda, Penicillus and Udotea-evidence from recent experiments and the geological record. Terra Nova 21: 323-339

Ries JB, Cohen AL, McCorkle DC (2009) Marine calcifiers exhibit mixed responses to $\mathrm{CO}_{2}$-induced ocean acidification. Geology 37:1131-1134

Rivera MG, Riosmena-Rodríguez R, Foster MS (2004) Age and growth of Lithothamnion muelleri (Corallinales, Rhodophyta) in the southwestern Gulf of California, 
Mexico. Cienc Mar 30:235-24

Rodolfo-Metalpa R, Houlbrèque F, Tambutté E, Boisson F and others (2011) Coral and mollusc resistance to ocean acidification adversely affected by warming. Nat Clim Change 1:308-312

Russell BD, Thompson JA, Falkenberg LJ, Connell SD (2009) Synergistic effects of climate change and local stressors: $\mathrm{CO}_{2}$ and nutrient-driven change in subtidal rocky habitats. Glob Change Biol 15:2153-2162

Editorial responsibility: Laura Airoldi,

Ravenna, Italy
Russell BD, Passarelli CA, Connell SD (2011) Forecasted $\mathrm{CO}_{2}$ modifies the influence of light in shaping subtidal habitat. J Phycol 47:744-752

Stewart JG (1982) Anchor species and epiphytes in intertidal algal turf. Pac Sci 36:45-60

Zou D (2005) Effects of elevated atmospheric $\mathrm{CO}_{2}$ on growth, photosynthesis and nitrogen metabolism in the economic brown seaweed, Hizikia fusiforme (Sargassaceae, Phaeophyta). Aquaculture 250:726-735

Submitted: February 29, 2012; Accepted: June 20, 2012

Proofs received from author(s): September 3, 2012 